\title{
Value co-destruction: A typology of resource misintegration manifestations
}

\begin{abstract}
Purpose - Actors who participate in co-created service experiences typically assume that they will experience improved well-being. However, a growing body of literature demonstrates that the reverse is also likely to be true, with one or more actors experiencing value co-destruction (VCD), rather than value co-creation, in the service system. Building on the notion of resource misintegration as a trigger of the VCD process, this article aims to offer a typology of resource misintegration manifestations and to present a dynamic conceptualization of the VCD process.
\end{abstract}

Design/methodology/approach - A systematic, iterative VCD literature review was conducted with a priori aims to uncover the manifestations of resource misintegration and illustrate its connection to VCD for an actor or actors.

Findings - Ten distinct manifestations of resource misintegration are identified that provide evidence or an early warning sign of the potential for negative well-being for one or more actors in the service system. Furthermore, a dynamic framework illustrates how an affected actor uses proactive and reactive coping and support resources to prevent VCD or restore well-being.

Originality/value - The study presents a typology of manifestations of resource misintegration that signal or warn of the potential for VCD, thus, providing an opportunity to prevent or curtail the VCD process.

Keywords Resource misintegration, Value co-destruction, Well-being domains, Coping mechanisms

Paper type Research paper 


\section{Introduction}

Consumers' ability to make use of their own resources and those of other customers or firms, to improve their own welfare and that of others through resource integration processes, is a fundamental tenet of value co-creation (VCC) (Vargo and Lusch, 2016). However, an emerging stream of value co-destruction (VCD) research (e.g., Plé and Chumpitaz Cáceres, 2010; Echeverri and Skålén, 2011; Smith, 2013; Cabiddu et al., 2019) demonstrates that resource integration processes do not always lead to increased well-being for all service systems, be they individual or organizational (Laamanen and Skålén, 2015). Indeed, adopting a VCD perspective offers a useful vantage point to better understand how resource integration may manifest among service systems.

Plé and Chumpitaz Cáceres (2010, p. 431) define VCD as “an interactional process between service systems that results in a decline in at least one of the systems' well-being". Here, a service system is interpreted as an arrangement of resources connected with other systems by value propositions (Spohrer et al., 2007). Despite the widespread adoption of this VCD definition, interpretations and operationalizations of the VCD process are varied, obscuring understanding and posing challenges for further development of the concept (see web appendix 1 for an overview of VCD process research). This lack of clarity has been documented by scholars (e.g., Lintula et al., 2017), leading Plé (2017) to call for further research on VCD.

As a way forward, Plé (2016) and Caridà et al. (2018) explicitly connect the VCC process with resource integration, whereby actors combine and use resources to co-create intended value (Vargo et al., 2008). Resource integration, as a concept, provides knowledge of different processes and forms of collaboration (Kleinaltenkamp et al., 2012). It represents a socio-cultural process that enables actors to become members of a service system, 
accessing, adapting and applying their available resources (e.g., people, technology, knowledge) to create intended or unintended and expected or unexpected well-being outcomes (Peters et al., 2014; Caridà et al., 2018). In other words, resource integration is not merely a juxtaposition of resources but an embedded process central to VCC (Caridà et al., 2018). Thus, "effective resource integration is characterised by the 'configurational fit' of resources, activities and processes that see matching (of resources) in terms of internal configuration within an actor - and external configuration for the whole network or a sub group within it" (Gummesson and Mele, 2010, p. 193). Although resource integration is fundamental to VCC, the ways it can lead to VCD have largely been ignored. This gap may be a function of the difficulty in directly observing or recognizing the causes of misintegration of resources by one or more actors, especially when the process is accidental. It highlights the need to delineate the symptoms or expressions of misintegration and their potential for VCD (Baron and Warnaby, 2011; Edvardsson et al., 2012; Kleinaltenkamp et al. 2012; Plé, 2016; Caridà et al., 2018).

Thus, a key aim of this article is to explore the range of potential manifestations of resource misintegration derived from the systematization and summarization of existing VCD research. This step is important because manifestations provide evidence or an early warning sign of the potential reduced well-being for one or more focal actors in the service system. As a result of this review, the aim is to present a dynamic conceptualization of the VCD process, whereby one or more human actors may experience reduced well-being across multiple life domains. In doing so, this study makes the following contributions to the VCD literature. First, the typology of the manifestations of resource misintegration draws out distinct patterns of causality and thus signals potential ways to prevent or manage the VCD process. Second, the conceptual framework, which explicitly links resource misintegration to the VCD process, reinforces that VCC and VCD are recursive value processes and may alternate or 
even co-exist for one or more actors in a system (Plé, 2016). Finally, the conceptual framework also illustrates the potential coping strategies and support resources that an actor can draw on to circumvent the VCD process following resource misintegration or restore well-being to an equilibrium state following VCD.

The remainder of this article proceeds as follows: First a review of the link between VCD and resource misintegration in the literature is established and then a resource misintegration manifestation typology, including suggested causes, is developed. This typology is then linked to the role of reduced well-being across actor's life domains and restoration mechanisms. Next, we offer a conceptual framework that describes the VCD process in practice. We conclude by delineating contributions to research and practice on VCD and discuss areas requiring further research.

\section{VCD process and its relationship to resource misintegration}

The link between integration of resources and VCC is well established in the service dominant logic of marketing (Vargo and Lusch, 2004). For example, Vargo et al. (2008) argue that value is co-created through the beneficial efforts of actors' applications of operant resources and sometimes through the use of operand resources, such as goods. McCollKennedy et al. (2012, p. 370) further define customer value co-creation as "benefit realized from integration of resources through activities and interactions with collaborators in the customer's service network". This optimistic view of resource application and integration is questioned by scholars such as Echeverri and Skålén (2011, p. 355), who note that "the main impression we get from the literature is that engaging in interactive value formation processes is conceived as unproblematic for the parties involved," which is unrealistic. 
Web appendix 1 offers a comprehensive overview of VCD process literature within marketing. It illustrates the different VCD perspectives, their core theoretical frameworks and key causes. A majority of studies build on Plé and Chumpitaz Cáceres’s (2010) conceptualization of VCD that suggests intentional and unintentional misuse of resources as triggers activating the process. Further, only one step in the process of resource integration, such as accessing, adapting and integrating resources (Akaka et al., 2012), needs to be suboptimal for VCD to occur. These studies adopt service-dominant logic as an overarching paradigm with a few also including other enabling theories such as the conservation of resources ( Smith et al., 2013), justice theory (Xu et al., 2014), strategic action field theory (Laamen and Skålén, 2015), consumer culture theory (Carù and Cova, 2015), social resource theory (Quanch and Thaichon, 2017) and object boundary theory (Uppström and Lönn, 2017), to name a few.

Broadly, the existing VCD studies can be divided into four types. First, there are studies that adopt a resource misuse perspective to describe the VCD process. For instance, Robertson et al. (2014) highlight the misuse of knowledge resources by platform users in an online health context as a trigger for VCD. Second there are studies that focus on identifying antecedents of resource misuse such as Vafeas et al. (2016), who demonstrate the client's absence of trust, inadequate communication, the agency's inadequate human capital and power imbalance as some of the main reasons for resource misuse, leading to sub-optimal value for involved parties.

Third, as an alternative perspective to identifying antecedents of VCD, Echeverri and Skålén (2011) take a practice theory approach, in which VCD is the result of integrating actors' deviation from routinized procedures, understandings and engagements. These authors argue that these deviations are manifested through misaligned or incongruent 
elements of practice. Studies such as Cova and Paranque (2012), Xu et al. (2014) and Camilleri and Neuhofer (2017) build on this approach. For example, Camilleri and Neuhofer (2017) illustrate elements of VCD practices in the context of Airbnb such as unclear communication between host and guests, host unable to solve problems etc. Although this approach is not inconsistent with resource misintegration, as misaligned processes or incongruent practices can be associated with resource misuse (e.g., Echeverri and Skålén 2011), it is limited; i.e. some actors will routinely adopt practices they know will destroy value for another or other actors while creating value for another or others. Furthermore, taking a resource integration perspective offers the advantage of increasing the transparency of the nature of resource deficiencies or restrictions sometimes put on actors by the contexts in which they are embedded.

Last, there are studies (e.g., Laamanen and Skalen, 2015, Lintula et al.,2017, Zhang et al., 2018) that focus on both causes of resource misuse (e.g., disparate goals and power inequality) and expressions of misuse (e.g., warning other customers using firm resources) to explain VCD occurrences in different contexts.

Few VCD process studies refer to the outcomes of the process in the form of decline in well-being. For example, Geer (2015) suggests obstruction of co-creation of value is a direct outcome of defection of co-creation, and Kashif and Zarkada (2015) argue customer misbehavior is a VCD manifestation that leads to damages in preconception of service quality, harms organisations' brand image, reduces morale of frontline employees and increase financial cost. Further, only a handful of studies (e.g., Smith, 2013; Hill et al., 2016) acknowledge the significance of mitigators to alleviate VCD outcomes. Hill et al. (2016) for instance, demonstrate how prisoners cope with anti-service beliefs by taking service quality in their hands, developing an alternate economy within a prison environment. 
In conclusion, there is a plethora of VCD process knowledge within the literature. However, there have been limited attempts to present a comprehensive overview of resource mis-integration manifestations and their likely impact on the VCD process and associated actors' well-being, or the types of interventions that may potentially thwart or curtail such processes.

Thus, a typology is well justified to parsimoniously represent the full gamut of negative resource-based activities. Some typologies have been developed with respect to VCD, but these are often context specific, such as that of Robertson et al. (2014) exploring online selfdiagnosis in health, or Greer (2015), who focuses on dysfunctional behavior in professional services. Thus, our aim is to offer a generalizable typology, identifying the manifestations or expressions of resource misintegration through a systematic literature review.

In forming the typology, it is recognized that VCD occurs over time and can be construed in terms of a series of steps. Akaka et al. (2012) argue for three steps in the value co-creation process. First, an actor must access specific kinds of resources through interactions so resources must be available through the network; second, as access to resources is not sufficient to co-create value, the actor needs to adapt or customize the resources to fit with other resources, so that the set of resources is the appropriate mix for the interaction (Plé, 2016); and third, the focal actor needs to combine and apply the resources to co-create value, with this step representing true resource integration (Akaka et al., 2012; Plé, 2016). Accordingly, resource deficiency or misuse at any step along the process may lead to VCD, because all three are necessary for VCC.

Scholars have adopted various descriptors for negative resource-based activities such as the misalignment of processes (Lefebvre and Plé 2011), misintegration and non-integration (Plé, 2016), lack of integration (Xu et al., 2014) and loss of resources (Lintula et al., 2017). 
Further, multiple terms have been introduced to replace the VCD process, including 'destruction of common value' (Jokubauskiene et al., 2014), 'value destruction' (Leo and Zainuddin, 2017), 'value co-contamination' (Williams et al., 2016), 'subsidence of value' (Dey et al., 2016), 'value diminution' (Vafeas et al., 2016) and 'value no creation' (Makkonen and Olkkonen 2017). This study adopts Plé's (2016) higher-order label of resource 'misintegration' rather than 'misuse', 'loss' or 'failure' because it is more inclusive of the stages of the resource integration process of access, adaptation or customization. Further, the term misintegration does not hint at actor motivation, which can be accidental or deliberate. Moreover, VCD is used as the preferred term to describe the process that leads to reduced well-being for one or more focal actors because of its wide adoption in the literature and the lack of compelling reason to introduce yet another term.

\section{Methodology}

\subsection{Identification of relevant literature}

To delineate diverse manifestations of resource misintegration, a systematic review of the VCD literature in April 2019 was undertaken. To ensure a systematic and transparent process (Cook et al., 1997), the procedures of Tranfield et al. (2003) were adapted. The authorial team participated in the process of classifying the set of articles, holding extensive discussions about how to delimit the subject area and sources. Consequently, the following words and phrases in the title, abstract or keywords were identified: 'value co-destruction', 'value destruction', 'co-destruction of value' and 'co-destruct' plus 'value'. Scopus, ProQuest and Science Direct were the databases used to search for academic articles within business or economics. Although an exhaustive study would include unpublished research, the search was limited to published, peer-reviewed research, as the aim was not a meta-analytic generalization of quantitative findings. For delimiting, the search was limited to journals 
ranked B or above in the Australian Business Dean Council's 2013 ranking system. However, a collection of conference papers and book chapters that were either referenced in the articles reviewed or presented at major service research conferences (i.e., SERVSIG, QUIS and Frontiers in Service) were added. This initial pool included 47 works, consisting of 35 journal articles, nine conference papers and three book chapters.

Next, some articles were discarded given the criterion that they must deal substantively with the topic instead of making only passing reference (Tranfield et al., 2003). Specifically, two authors determined whether an article substantively addressed the topic. To minimize error and bias, a data extraction file consisting of publication details was created. This file was then circulated among the authorial team for perusal (Tranfield et al., 2003). This process also ensured face validity, as no published study known to the authorial team appeared to be missing in the list generated. Overall, six articles were excluded, resulting in a final set of 45 VCD articles as shown in web appendix 1.

\subsection{Development of resource misintegration manifestations}

Literature was synthesized to identify categories of expressions of resource misintegration through an iterative approach. Resource misintegration reflects how actors fail to access, adapt, combine or apply resources in ways contrary to their intended use as perceived by them or another or other actors. Each author examined a sample of the articles to identify examples of potential resource misintegration to develop categories of manifestations. The entire authorial team then reviewed and discussed these categories by following the constant comparative method (Lincoln and Guba, 1985). Accordingly, a match-or-contrast approach generated categories representing resource integration manifestations that served as unique descriptors and corresponding definitions. This approach was repeated with a second set of articles, to further expand on and refine the categories and definitions. 
A double-data extraction process helped extract the necessary information from each article (Tranfield et al., 2003). Specifically, the authorial team, which was split into three pairs, examined a subset of the articles such that all members reviewed the entire list of articles generated. The information collected included: (1) the definition of VCD (or synonyms) used; (2) the definition of resource misintegration (or synonyms) used, if at all; and (3) the potential descriptive examples of symptoms or signs of resource misintegration cited. Each team member independently categorized the examples using the schema developed by the team. Next, each pair swapped sets of articles and repeated the categorization process independently. The inter-rater reliability (Perreault and Leigh, 1989) averaged $84 \%$ and ranged from $71 \%$ to $98 \%$ across the three author pairs. The differences across pairs were relatively small, and resolution on differences was readily reached.

\section{Typology of resource misintegration manifestations}

The co-creation of value suggests several assumptions for the mutual benefit of all actors involved in the exchange. These may include equal status and, consequently, equal power of the interacting actors; voluntary resource integration without coercion; and, for all actors, full disclosure (i.e., adequate knowledge of the costs of resource integration and exchange alternatives). Such conditions for the equitable betterment of all interacting actors rarely exist however. Instead, actors may fail to co-create value for themselves or others through the process of resource misintegration, which we recognize as distinct manifestations. A manifestation is not a cause (e.g. poor communication, absence of trust, insufficient human capital or power imbalances, see Vafeas et al., 2016), but a visible display, demonstration, or sign or expression that resource misintegration has occurred. We identify 10 distinct manifestations along the resource integration process of access, adapt, and combine and apply. 
The first three categories suggest that the resources of at least one interacting actor were not integrated for VCC and refer to the access stage of resource integration. These include (1) lack of resources to integrate, (2) blocked access to integrate resources, and (3) unwillingness to integrate resources. The next four categories refer to the adapt stage of resource integration and include (4) misunderstanding of how to integrate resources, (5) disagreement on how to integrate resources, (6) deceptive integration of resources, and (7) negligent integration of resources. The final three categories refer to the combine and apply stage of resource integration and include (8) incapacity to integrate resources, (9) excessive integration of resources, and (10) coercive integration of resources.

While the analysis attempted to distill discrete manifestations, it is acknowledged that they are not mutually exclusive and that there are likely to be spillover effects and interrelationships between the categories. This acknowledgement also suggests there may be situations in which a combination of these manifestations occurs within a single resource misintegration process. In the following section, each resource misintegration manifestations is described sequentially across resource integration process of access, adapt, combine and apply.

\subsection{Resource integration process of access}

Lack of resources to integrate denotes the unavailability of resources or the belief of such by at least one interacting actor. Time is a common and scarce resource that falls into this category, but a lack of resources can also include personnel, technology, facilities, equipment and finances. In these situations, some interacting actors assume that the resources are available for integration, which may not be the case. In addition, some actors do not possess the necessary mental (Paredes et al., 2014) or physical capabilities to integrate, or they 
possess them but lack the self-confidence or belief to do so. An example is government agencies assuming that the elderly can register their needs through online applications.

Blocked access to integrate resources denotes the deliberate restriction or prevention of resource integration by at least one interacting actor (e.g., children prevented from accessing social media by their parents). This prevention is independent of whether an interacting actor possesses resources for integration or is qualified. Blocked access or obstruction is often exemplified by one or more actors eliminating the opportunities for other actors to integrate resources (Camilleri and Neuhofer, 2017), such as by tying up channels of distribution or not granting authority. Such actions can be due to biases, stereotypes and prejudices. For example, government officials may use race, ethnicity, sexuality, wealth or religion to determine access to information, employment, housing, visas and other valuable services (Williams et al., 2016). Another example is spectators at a football match being prevented from actively supporting their team by intensely loyal fans during a silent protest game (Stieler et al., 2014).

Unwillingness to integrate resources denotes the deliberate withholding or withdrawing of resources by at least one interacting actor. This type of resource misintegration may be due to an actor's voluntary deprivation or simplification, defiance, protection or sabotage, or it may simply be a means for the actor to regain perceived control. Examples include channel members who refuse to work with another (Skalen, 2011), a customer who fails to show up for an appointment or refuses to provide identification or disclose financial information, a cancer patient who forgoes chemotherapy, or a kidney disease patient who rejects dialysis, a student who refuses to engage at school, or parents who refrain from cooperating with the police to protect their child. This manifestation may also be expressed by a frontline employee who withholds or dramatically slows down service for a rude customer as an act of 
revenge, or by firms that refrain from serving certain markets because of their remoteness or lack of financial feasibility (Dey et al., 2016).

\subsection{Resource integration process of adapt}

Misunderstanding of how to integrate resources refers to the unintentional failure to understand how to correctly integrate resources by at least one interacting actor, such as when a customer is not socialized or sufficiently informed of the service script, resulting in frustrations, delays and poor experience. Alternatively, when firms' product design and/or marketing strategies are not sympathetic to the local language, lifestyle and culture of the intended beneficiary (Dey et al., 2016), unintentional failure may also occur.

Disagreement on how to integrate resources denotes the failure to agree on how best to integrate resources by at least two interacting actors. This type of resource misintegration may occur when actors are in conflict, believe their process is superior, are reluctant to cede control or status (Williams et al., 2016) or insist on acting selfishly. Examples include when a client demands that a service provider implement what the client believes is necessary rather than listening to expert advice, or when frontline employees begrudgingly supervise selfservice kiosks rather than personally serving customers. Alternatively, such resource misintegration may simply be due to ineffective sharing of information between actors.

\section{Deceptive integration of resources refers to the deliberate concealment or} misrepresentation during resource integration by at least one interacting actor. An example is when a utility provider promises to repair a cable at a defined time, but continuously fails to show up, despite multiple follow-ups from the customer (Smith, 2013). Other examples include a law firm is being not transparent in its billing or when a customer checks into a hotel only to use the room to carry out illegal activities (e.g., narcotics, prostitution). Fake news, ad busting, vandalism, theft, posting false or exaggerated negative content on social 
media brand pages, or account hacking to exploit a resource are other examples of deceptive integration, which typically involves opportunistic, unethical and unlawful behaviors.

Negligent integration of resources is the deliberate inattention and carelessness in the integration of resources by at least one interacting actor. It may be expressed in the form of non-receptivity (Malshe and Friend, 2017), which includes actor apathy, ambivalence or annoyance in having to integrate resources. Examples include a not-for-profit's poor management that leads to volunteers experiencing high role ambiguity, or when customers fail to service their cars until they break down.

\subsection{Resource integration process of combine and apply stage}

Incapacity to integrate resources alludes to the disqualification to integrate resources by at least one interacting actor. In contrast with lack of resources in which an actor does not possess the resources for integration, with, an interacting actor believes that he or she has the resources to integrate, but other interacting actors believe otherwise. For example, incapacity may occur in situations in which the actor is disqualified through ineligibility or lack of credentials or experience or is simply perceived as being unfit to integrate resources. Vafeas et al. (2016) explain how advertising agencies lament that clients cannot legitimately judge creative work because they lack the training to do so. Similarly, disqualification occurs when consumers engage in self-diagnosis and self-medication based on their interpretation of information gathered on the web because they are unable to critically evaluate the quality and relevance of the information (Robertson et al., 2014). Actors may also be unfit to integrate resources if they are physically or mentally incapacitated (e.g., ill, injured, intoxicated), or ineligible through government policies or law (e.g., lack of a driver's license or work visa, failing a background check to work with children). 
Excessive integration of resources describes the extreme application of resources by at least one interacting actor. Examples include when clients email their financial planner in excess of five times a day (Greer, 2015), or when a customer obsesses over a brand, dominating online community forums and pestering the firm for dates of new product releases. Similarly, players can become addicted to an online game, which is encouraged by online social pressure. This type of resource misintegration is also exemplified when a firm sends excessive texts or emails to a customer on promotions that the customer views as intrusive and annoying spam. Excessive resource integration may also be expressed as sexual harassment, aggression, rage or cyberbullying.

Finally, coercive integration of resources refers to involuntary, forced or constrained resource integration by at least one interacting actor. This expression of resource misintegration can occur in exchange interactions in which an actor lacks control and agency, such as when an actor has little autonomy or ability to control their own resources (Zeitz, 1980). These types of situations may arise from resource dependence, whether real or imagined, and are grounded in perceptions of a lack of suitable alternative sources (Scheer $e t$ al., 2015). The lack of control and agency may also be a result of the imbalanced or inequitable power and authority of one actor, whose dominance can coerce other actors to engage in the resource integration process (Zeitz, 1980), such as when high-value, entitled customers threaten to take their business elsewhere if their special requests are not met (Wetzel et al., 2014). Extreme examples of coercive integration include forced or bonded labor in the context of human trafficking, domestic servitude, forced marriages, sexual services and even unlawful imprisonment (Williams et al., 2016).

Table 1 provides further illustrative examples of the 10 resource misintegration manifestations from the perspective of the affected human actor (e.g., the service provider, frontline employee, customer, other customers) at risk of experiencing VCD. The examples 
represent how different actors in a service system can misintegrate resources either deliberately or accidentally and trigger VCD for a focal actor. As the table shows, although some manifestations of resource misintegration are accidental (e.g., misunderstanding how to integrate resources), the majority arise through the intentional actions of at least one interacting actor. This is followed by Table 2 which provides suggestive causes for the different forms of resource mis-integration manifestations which have been predominantly derived from the literature synthesis presented in the web appendix.

[insert Table 1]

[insert Table 2]

\section{Reduced well-being as an integral component of VCD}

The resource misintegration examples in Table 1 illustrate how the VCD process may be triggered by one or more actors. Whether VCD and the associated reduced well-being across one or more life domains occur depends on the focal actor's coping strategies and resources.

\subsection{Well-being across life domains}

Subjective well-being refers to the quality of a person's life (Lee et al., 2002) and is a highly desirable outcome of successful service provision. Research has begun connecting VCC with the outcome of well-being, such as in the context of health (e.g., McColl-Kennedy et al., 2012; Sweeney et al., 2015). However, though grounded in the definition of VCD, the connection between VCD and actors' well-being is often ignored.

Similar to value, well-being is actor-defined and therefore is a subjective, individualist and contextual assessment of the status of one's own life (Ryff and Keyes, 1995; Sirgy and Lee, 1996; Diener et al., 1999; Lusch and Vargo, 2014). Extant well-being and service 
literature captures actors' well-being assessments using the life domain approach (e.g., Diener et al., 1999). Focusing on domains of well-being rather than well-being holistically offers the advantage of gaining richer insight into the ways a focal actor may experience VCD. Furthermore, it enables delineation of the strategies that a focal actor and other actors in the network, including organizations and governments, can adopt to either mitigate the negative displacement in well-being or hasten its restoration.

Six key life domains from the well-being literature are adopted to illustrate VCD (e.g., Lee et al., 2002). First, professional well-being refers to actors' evaluation of their state of career development and workplace experiences (e.g., Maggiori et al., 2013); negative displacement in this domain may be experienced as role ambiguity, burnout or job loss. Second, leisure well-being refers to focal actors' evaluation of their leisure activities and involvement (e.g., Sirgy et al., 2017); negative displacement in this domain may be experienced as less time to engage in or less hedonic enjoyment obtained from leisure activities. Third, financial well-being refers to the focal actors' evaluation of their state of financial security and status (e.g., Gerrans et al., 2014); a loss in financial well-being may be experienced as a reduction of lifestyle comfort and security. Fourth, health and safety wellbeing refers to focal actors' evaluation of their physical health conditions (e.g., Danna and Griffin, 1999); negative displacement may be experienced as poor health and mobility. Fifth, emotional well-being refers to focal actors' evaluation of their emotional state; a reduction can be experienced as negative felt emotions (Fredrickson and Joiner, 2002), such as anger, sadness, anxiety or fear. Last, social well-being refers to focal actors' sense of belongingness and positive relationships with others (e.g., Ryff and Keyes, 1995); a decrease in social wellbeing can be experienced as isolation, loneliness and/or loss of trust in others. 
Actors assess their well-being on the basis of the resources they possess to meet specific challenges or face events (Lee et al., 2002) in various life domains. Thus, the absence or restriction of resources is likely to result in reduced well-being during challenging events. Service scholars (e.g., Sweeney et al., 2015) suggest that actors' well-being derives from the resources they use during activities they undertake, the forms of interactions they engage in with others in a service network, and the roles they adopt in the resource integration process. Given that resource misintegration can potentially trigger the VCD process for an actor, the consequences of this process are diminished well-being across one or more life domains, resulting in a decline in overall well-being (e.g., Lee et al., 2002). Despite the importance of well-being to the VCD process, to our knowledge no service research has attempted to understand the decline in well-being across different life domains. Thus, examining well-being life domains will offer in-depth understanding of the type of well-being reduction focal actors experience and how they can restore well-being.

\subsection{Restoration of well-being}

Although a focal actor's well-being may be reduced through the VCD process, dynamic equilibrium theory proposes that individuals have a normal steady-state pattern of well-being (Headey and Wearing, 1989). Thus, a reduction in well-being is typically temporary, even in severe cases. Suh et al. (1996) show that the impact of most life events on subjective wellbeing diminishes after three months.

Two theoretical strands of literature show how a stable state of equilibrium can be restored by reducing stress. The first strand focuses on coping strategies, or actors' efforts to manage the internal and external demands of situations apprised as stressful (Folkman and Moskowitz, 2004). The second strand pertains to conservation of resources (COR) theory, which argues that people strive to obtain, retain, protect and foster valued resources to 
minimize any threats of resource loss (Hobfoll 1989, 2011; Smith, 2013). A central tenet of COR is that people must invest resources to protect against resource loss, recover from loss and gain resources (Hobfoll, 2011). The two theoretical approaches are connected, as COR posits that after an interaction resulting in resource depletion and loss of well-being, some individuals engage in coping strategies to restore well-being through the activation of resources (Smith, 2013). According to COR, individuals use their existing resources to gain new resources. For example, when experiencing loss of resources through job demands, an employee can gain resources such as a sense of competence and relatedness following cooperative interactions with customers. Thus, actors undertaking coping strategies and/or resource conservation to manage their negative resource loss can adapt to changes in their expected value and restore well-being to the state of equilibrium (Headey and Wearing, 1989).

Actors do not typically enter into an exchange with the expectation of reduced wellbeing as the outcome. The proposed typology shows, however, that resource misintegration is often a deliberate action by an interacting actor who opportunistically maximizes benefits to the self. Thus, the ability to avoid VCD and its associated negative well-being displacement depends on context and the degree to which the focal actor is experiencing VCC at that point in time through other exchange interactions. It also depends on whether the affected actor can undertake proactive or reactive coping through the use of his or her support networks; that can help circumvent or restore the impact of VCD.

In proactive coping, an actor predicts future risks, demands, behavioral actions and opportunities. The resource misintegration event is not appraised as harm or a loss of wellbeing (Schwarzer and Taubert, 2002); rather, the affected actor senses the event as a challenge and uses it constructively to improve life and access resources to ensure progress and quality of functioning. With such preventive actions, the focal actor may effectively 
offset any future loss of well-being (Schwarzer and Taubert, 2002) and thus thwart the VCD process. Even when well-being is negatively displaced, as defined by the VCD process, the focal actor can prompt reactive coping mechanisms to speed up the restoration of well-being to its equilibrium state (Schwarzer and Taubert, 2002). For example, during reactive coping, the focal actor may engage in avoidance strategies, such as mental or behavioral disengagement (e.g., switching service providers) (Moring et al., 2011). Regardless of whether proactive and/or reactive coping strategies are used, the focal actor can further draw on contextual support resources in the network to enhance coping. Ultimately, the focal actor auto-regulates to maintain a stable level of stock (required resources and skills) and flow (satisfaction or distress), a process known as homeostasis (Cummins, 2010). Three contextual support resources are suggested that can assist the focal actor in undertaking proactive and reactive coping strategies that may help prevent the initiation of VCD or facilitate the homeostasis process: social, commercial and regulatory support.

First, social support resources, which derive from close ties such as family and friends, affect the choice or regularity of the use of coping strategies and, consequently, affect wellbeing (Kim et al., 2010). Moreover, social networks can offer support even without realization by the actor (Taylor, 2011). For example, Kim et al. (2010) show that social support helps cancer patients use more positive reframing and fewer self-blame strategies.

Second, commercial support resources refer to the contextual influences of service providers and employees, competitors and consumer communities that exist in an actors' network. A service provider or employee can proactively engage in recovery strategies that prevent the initiation of VCD for the focal actor. In addition, commercial competition among service providers offers actors more alternatives and the freedom of choice (Fornell, 1992) to help them cope with the VCD process and restore diminished well-being. There are also 
formal associations or advocacy groups which assist actors in dealing with exploitation through protests, litigation, campaigning and lobbying (Hilton, 2009).

Third, regulatory support resources refer to the contextual influence of industry or government legislation that provides regulatory protection or retribution to actors. For example, governments can offer strong protection to both customers and employees against unfair practices through legislation. Such mechanisms can also act as a safety net to affected actors seeking restitution through protection agencies, enabling the restoration of well-being.

\subsection{VCD conceptual framework}

Figure 1 illustrates the dynamic process by which VCC and VCD may occur concurrently for a focal actor, resulting in a net displacement in well-being that is either enhanced or diminished at a given point in time. In the case of reduced well-being or a negative change in the equilibrium state, actors tend to return to the equilibrium state through mechanisms such as coping and resource conservation. Social, commercial and regulatory support can also be used to compensate for the loss of resources.

\section{[Insert Figure 1]}

Using media reports and academic literature on the introduction of social robots in nursing homes we develop this hypothetical example to illustrate the VCD conceptual framework, as it links resource misintegration manifestations to the domains of well-being. It also helps demonstrate the role of coping and support resources for the focal affected actor.

Social robots are becoming prevalent in aged care because they improve the quality of healthcare services and patient health outcomes (Olaronke et al., 2017). Elderly residents often experience VCC in the form of improved social well-being as the robots help mitigate their boredom and offer companionship, entertainment and comfort. The management of the 
nursing home also benefits by saving money (financial well-being) because the robots are not susceptible to human concerns such as sickness or boredom due to repetition, and they can readily be programmed to adapt to changing conditions in their environment (Davids, 2017).

However, sometimes the use of robots in aged care may not lead to an ideal outcome for the intended beneficiary or may result in negative outcomes for others in the value network (e.g., Sparrow, 2016). For example, caregivers and nurses do not view the robots as a means to enhance their productivity and complement their efforts but rather as a threat to their livelihood (Ljungblad et al., 2012). Thus, the use of social robots affects their professional well-being as the nature of their work has changed to a focus on compliance, monitoring and treatment rather than resident care (disagreement on how to integrate resources). Furthermore, management insists that they work with social robots under the threat of being assigned undesirable shifts if they do otherwise (coercive integration of resources). Despite this requirement, some staff members still attempt to sabotage the robots by repeatedly asking them confusing questions or making silly requests (unwillingness to integrate resources). Others choose to ignore the robots and try to carry on as before (negligent integration of resources), hoping that their use is a passing management fad. Still others vent to their colleagues and in fear of being punished, quickly adapt (coercive integration of resources) by viewing the robots as co-workers.

Some of the residents' family members also have low acceptance of the robots and thus experience a reduction in health and safety well-being, as they worry about the chance of malfunction and the appropriateness of using robots in such a context. They also feel guilty that their vulnerable loved ones are being cared for by a non-living entity (reduced emotional well-being). Some have noticed a deterioration in their relationship (social well-being) over time, as their loved ones become emotionally attached to or even obsessed with the robot 
(excessive integration of resources) and display little interest when they come to visit. They also fear a loss of privacy for their family member (reduced health and safety well-being) as the robots constantly gather data through their sensors (e.g., cameras). Management insist this data are only used to improve the welfare of the residents, such as the early detection of accidents (Čaić et al., 2018). While some family members have written to their local council to act on legislation that will protect the privacy of their loved ones (regulatory support resource), others have joined forces with the local Nursing Association to limit the reliance on robots in such settings (commercial support resource). Some family members have even transferred their loved ones to another aged-care facility (reactive coping), while others have adjusted and are enjoying the new-found freedom of not having to feel guilty when they do not visit the aged-care facility regularly (value co-creation).

\section{Discussion}

\subsection{Theoretical contributions and managerial implications}

This article responds to recent calls in the literature to better understand the process of resource (mis)integration (Plé, 2016; Caridà et al., 2018) and its role in triggering VCD (Grönroos, 2011), by offering a comprehensive typology of resource misintegration manifestations. The expanded typology helps enhance the understanding of VCD in that unlike prior research, which has focused strongly on service failure and customer misbehavior (resulting from firm and customer actions respectively) as potential determinants of VCD (refer to web-appendix for details), the typology highlights a more comprehensive set of potential causes of VCD. Importantly, some of these triggers include deliberate or planned actions on the part of firms or service providers, such as active prevention of resource integration, resource integration under coercive conditions or withdrawal of 
resources necessary for integration to take place. Despite the prevalence of such actions in business practice, our review indicated that these forms of resource misintegration appear to be under-researched, especially relative to the topics of service failure and customer misbehavior. Thus, the typology contributes towards the further conceptual development of the VCD literature stream through envisioning, identified by MacInnis (2011) as one important way of making a conceptual contribution: Specifically, the study identifies new forms of resource mis-integration, and also help revise the way scholars can look at misintegration categories more holistically.

Furthermore, the proposed process model of VCD is dynamic and is conceptually underpinned by the equilibrium theory that illustrates the potential for restoration of wellbeing in different life domains. With few exceptions (e.g., Echeverri and Skålén, 2011; CarùsD and Cova, 2015; Chavi et al., 2017), VCC and VCD have often been portrayed as distinct occurrences. The study clearly demonstrate that these two processes can occur simultaneously depending on the focal actor's perspective, as illustrated by the social robot case. The process model highlights how the potential impact of resource misintegration can be mitigated by proactive coping mechanisms in some cases and how the actor's reactive coping, supported by social, commercial and regulatory resources, can help speed up the return of well-being equilibrium in a specific domain in other cases.

The model proposed herein also has important managerial implications. One of the key benefits of identifying a comprehensive set of resource misintegration manifestations is that it enables the root causes of VCD to be established. Firms often address value co-destruction reactively, after it has occurred. The manifestations and root causes enable a practical approach to manage VCD, specifically in preventing VCD from happening in the first place. For example, when there is potential for a misunderstanding of how to integrate resources 
correctly, socialization between actors, and scripts for providers as well as customers can be helpful preventive mechanisms. For instance, some sharing economy platforms provide their customers with scripts or draft email messages that can be customized by the users to communicate with each other, thereby minimizing the misunderstanding of how to integrate resources correctly.

This research further illustrates how a manager or other stakeholders can anticipate and prevent VCD by actively scanning for the potential causes of resource mis-integration manifestations, with two current examples from industry. The recent airline accidents involving the Boeing 737 Max 8, where the pilots were first unable to respond to a faulty signal, and then had their ability to correct the faulty technology overridden by the software (Shephardson, 2019), demonstrates a number of potential causes of resource misintegration. There was a serious misunderstanding of how to integrate resources optimally caused by inadequate pilot training, and disagreement on how to integrate resources caused by a lack of pilot control. Although these causes of misintegration were likely unintentional, VCD could have been mitigated by addressing the root causes; specifically, adequate pilot simulation training and changes to decision control during the aircraft's instrument design stage.

Similarly, media has been replete with news about recent bank closures in rural communities in a number of provinces in Canada. These closures have been found to impact access to banking services and lead to inequity (CBC news, 2018). When such rural customers or senior citizens are blocked access to certain resources because of lack of technology or lack of a physical distribution channel, VCD is likely impacting their well-being. Such intentional restrictions often arise out of biases, power imbalances, or even due to business norms (as identified in Table 2). Some customers will proactively cope with such limited access, while others will burden the resources of support networks. Yet, others will simply endure their 
state of poor well-being indefinitely unless external interventions are applied. While firms may not proactively address such potential causes of resource mis-integration as they are intentional, other stakeholders such as regulatory bodies can indeed detect such manifestations and take proactive measures to mitigate VCD.

\subsection{Limitations and further research}

Similar to Plé (2016), this study does not adopt an ecosystems perspective; instead, the analysis remains at the micro-level of human actor-to-actor interactions as this dominated the research, we drew from to construct our typology. Regardless, unlike Plé (2016), this study extends beyond the service employee-customer dyad and consider other actors, including other supply chain members and online communities. As this study offers a restricted view of the VCD process and its impact on collective well-being (Anderson et al., 2013), future research could develop VCD frameworks that capture its impact on organizational, community or system well-being.

The typology of manifestations of resource misintegration and VCD process model offer a useful point of reference for future empirical studies. Specifically, the extensive review indicates that scant research has empirically validated the VCD process. The conceptual model depicts how resource misintegration can potentially lead to VCD and associated reduced well-being, resulting in a negatively displaced equilibrium that can be restored through actors' reaction coping processes supported by social, commercial or regulatory support resources. Thus, longitudinal studies are required to ensure that the temporal extent of the analysis is consistent with the time it takes for the resource misintegration to impact actor well-being (if at all). It is also imperative to test the VCD process model to shed light on the time it takes to restore well-being given contextual factors and the severity of the VCD process experienced. Such studies may also enable the 
assessment of whether a particular step in the resource integration process (i.e., access, adapt or apply) (Akaka et al., 2012) is more prone to accidental or deliberate resource misintegration and whether the type of resource misintegration manifestation is linked to how difficult or easy it is for the affected actor to learn, adapt or correct it to reach well-being homeostasis.

The focus in this study was on identifying the manifestations of resource misintegration and then understanding the mechanisms actors can use to either proactively prevent the VCD process or reactively revert to a steady state when well-being has been diminished. We did not specifically address ways to prevent resource misintegration, though the indicative causes behind each type of manifestation infer such strategies. As illustrated through numerous examples herein, resource misintegration is not limited to service failure situations and can include deliberate actions on the part of an actor, ignorant and systematic actions of a firm, and other market-facing, public and private sources. The categories are diverse, as are the underlying causes. The prevention or remedial action of such resource misintegration requires the active sensing of the service system. Future research needs to focus on these issues if service exchanges are to lead to mutual betterment which is consistent with recent calls for "better marketing for a better world" (Moorman, 2018). 


\section{References}

Akaka, M.A., Vargo, S.L., and Lusch, R.F. (2012), “An exploration of networks in value cocreation: a service-ecosystems view", Review of Marketing Research, Vol. 9, pp. 13-50.

Baron, S. and Warnaby, G. (2011), "Individual customers' use and integration of resources: empirical findings and organizational implications in the context of value cocreation", Industrial Marketing Management, Vol. 40 No. 2, pp. 211-218.

Cabiddu, F., Moreno, F. and Sebastiano, L. (2019), "Toxic collaborations: co-destroying value in the B2B context", Journal of Service Research, Vol. 22 No. 3, pp. 241-255.

CBC News (2018), Bank closures in rural communities impact access, equity says professor, accessed, August $14^{\text {th }}, 2019$, https://www.cbc.ca/news/canada/thunder-bay/bankclosures-rural-communities-access-equity-1.4765038

Čaić, M, Odekerken-Schröder, G. and Mahr, D. (2018), "Service robots: value co-creation and co-destruction in elderly care networks", Journal of Service Management, Vol. 29 No. 2, pp. 178-205.

Camilleri, J. and Neuhofer, B. (2017), "Value co-creation and co-destruction in the Airbnb sharing economy", International Journal of Contemporary Hospitality Management, Vol. 29 No. 9, pp. 2322-2340.

Caridà, A., Edvardsson, B. and Colurcio, M. (2018), “Conceptualizing resource integration as an embedded process: matching, resourcing and valuing", Marketing Theory, Vol. 12 No. 2, pp. 201-205.

Carù, A. and Cova, B., (2015), "Co-creating the collective service experience", Journal of Service Management, Vol. 26 No. 2, pp.276-294.

Cova, B. and Paranque, B., (2012), "Value creation versus destruction: the relationship between consumers, marketers and financiers", Journal of Brand Management, Vol. 20 No. 2, pp.147-158. 
Chavi, C.Y., Plé, L. and Zhu, X., (2017), “The dynamics between value co-creation and Value Co-destruction in Business Service Networks", in Marketing at the Confluence between Entertainment and Analytics Springer, Cham, pp. 1325-1325.

Cook, D. J., Greengold, N.L., Ellrodt, A.G. and Weingarten, S.R. (1997), “The relation between systematic reviews and practice guidelines", Annals of Internal Medicine, Vol. 127 No. 3, pp. 210-216.

Cummins, R.A. (2010), “Subjective wellbeing, homeostatically protected mood and depression: a synthesis”, Journal of Happiness Studies, Vol. 11 No. 1, pp. 1-17.

Danna, K. and Griffin, R.W. (1999), "Health and well-being in the workplace: a review and synthesis of the literature”, Journal of Management, Vol. 25 No. 3, pp. 357-384.

Davids, M. (2017), "5 ways robots perform mundane tasks better than humans", available at: https://blog.robotiq.com/5-ways-robots-perform-mundane-tasks-better-than-humans (accessed 27 July 2017).

Dey, B.L., Pandit, A., Saren, M., Bhowmick, S. and Woodruffe-Burton, H. (2016), “Cocreation of value at the bottom of the pyramid: analysing Bangladeshi farmers' use of mobile telephony”, Journal of Retailing and Consumer Services, Vol. 29, pp. 4048.

Diener, E., Suh, E.M., Lucas, R.E. and Smith, H.L. (1999), "Subjective well-being: three decades of progress", Psychological Bulletin, Vol. 125 No. 2, pp. 276-302.

Echeverri, P. and Skålén, P. (2011), “Co-creation and co-destruction: a practice-theory based study of interactive value formation”, Marketing Theory, Vol. 11 No. 3, pp. 351373.

Edvardsson, B., Skålén P. and Tronvoll, B. (2012), "Service systems as a foundation for resource integration and value co-creation”, in Vargo, S.L. and Lusch, R.F. (Eds.), Special Issue-Toward a Better Understanding of the Role of Value in Markets and Marketing, Emerald Group Publishing Limited, West Yorkshire, UK, pp. 79-12. 
Folkman, S., and Moskowitz, J. (2004), “Coping: pitfalls and promise”, Annual Review of Psychology, Vol. 55, pp. 745-774.

Fornell, C. (1992), "A national customer satisfaction barometer: the Swedish experience", Journal of Marketing, Vol. 56 No. 1, pp. 6-21.

Fredrickson, B.L. and Joiner, T. (2002), "Positive emotions trigger upward spirals toward emotional well-being”, Psychological Science, Vol. 13 No. 2, pp. 172-175.

Gerrans, P., Speelman, C. and Campitelli, G. (2014), "The relationship between personal financial wellness and financial wellbeing: a structural equation modelling approach”, Journal of Family and Economic Issues, Vol. 35 No. 2, pp. 145-160.

Greer, D. A. (2015), "Defective co-creation: developing a typology of consumer dysfunction in professional services", European Journal of Marketing, Vol. 49 No. 1/2, pp. 238261.

Grönroos, C. (2011), "Value co-creation in service logic: a critical analysis", Marketing Theory, Vol. 11 No. 3, pp. 279-301.

Gummesson, E. and Mele, C. (2010), "Marketing as value co-creation through network interaction and resource integration", Journal of Business Market Management, Vol. 4 No. 4, pp. 181-198.

Headey, B. and Wearing, A., (1989), "Personality, life events, and subjective well-being: toward a dynamic equilibrium model", Journal of Personality and Social Psychology, Vol. 57 No. 4, pp.731-739.

Hilton, M. (2009), Prosperity for All: Consumer Activism in an Era of Globalization, Cornell University Press, New York.

Hill, R.P., Capella, M.L., Rapp, J.M. and Gentlemen, G., (2016), “Antiservice as Guiding Maxim: tough lessons from a maximum security prison", Journal of Service Research, Vol. 19 No. 1, pp.57-71.

Hobfoll, S.E. (1989), “Conservation of resources: a new attempt at conceptualizing stress”, American Psychologist, Vol. 44 No. 3, pp. 513-524. 
Hobfoll, S.E. (2011), “Commentary: conservation of resource caravans and engaged settings", Journal of Occupational and Organizational Psychology, Vol. 84, pp. 116122.

Jokubauskiene, R., Patašienè, I., Bakanovè, A. and Patašius, M. (2014), “Model for evaluation of co-creation possibilities in the enterprise of knowledge-intensive business services”, Social Sciences, Vol. 83 No. 1, pp. 7-16.

Kashif, M. and Zarkada, A., (2015), "Value co-destruction between customers and frontline employees: a social system perspective", International Journal of Bank Marketing, Vol. 33 No. 6, pp.672-691.

Kim, J., Han, J.Y., Shaw, B., McTavish, F. and Gustafson, D. (2010), “The roles of social support and coping strategies in predicting breast cancer patients' emotional wellbeing: testing mediation and moderation models", Journal of Health Psychology, Vol. 15 No. 4, pp. 543-552.

Kleinaltenkamp, M., Brodie, R.J., Frow, P., Hughes, T., Peters, L.D. and Woratschek, H. (2012), "Resource integration”, Marketing Theory, Vol. 12 No. 2, pp. 201-205.

Laamanen, M. and Skålén, P. (2015), "Collective-conflictual value co-creation: a strategic action field approach", Marketing Theory, Vol. 15 No. 3, pp. 381-400.

Lee, D.J., Sirgy, M.J., Larsen, V. and Wright, N.D. (2002), "Developing a subjective measure of consumer well-being”, Journal of Macromarketing, Vol. 22 No. 2, pp. 158-169.

Lefebvre, I. and Plé, L. (2011), "Emergence of value co-destruction in B2B context”, in Gummesson, E., Mele, C. and Polese, F. (Eds.), Service Dominant Logic, Network \& Systems Theory and Service Science: Integrating Three Perspectives for a New Service Agenda, Giannini, Napoli, Italy, pp. 1-28.

Leo, C. and Zainuddin, N. (2017), "Exploring value destruction in social marketing services", Journal of Social Marketing, Vol. 7 No. 4, pp. 405-422. 
Lincoln, Y.S. and Guba, E.G. (1985), Naturalistic Inquiry, Sage, Thousand Oaks, CA.

Lintula, J., Tuunanen, T. and Salo, M. (2017), “Conceptualizing the value co-destruction process for service systems: literature review and synthesis", in Proceedings of the 50th Hawaii International Conference on System Sciences (HICSS 2017), IEEE Computer Society, Hawaii, pp. 1632-1641.

Ljungblad, S., S., Kotrbova, J., Jacobsson, M., Cramer, H. and Niechwiadowicz, K. (2012), "Hospital robot at work: something alien or an intelligent colleague?", in Proceedings of the ACM 2012 conference on Computer Supported Cooperative Work, ACM, New York, pp. 177-186.

Lusch, R.F. and Vargo, S.L. (2014), Service-Dominant Logic: Premises, Perspectives, Possibilities, Cambridge University Press, Cambridge, UK.

Maggiori, C., Johnston, C.S., Krings, F., Massoudi, K. and Rossier, J. (2013), “The role of career adaptability and work conditions on general and professional well-being", Journal of Vocational Behavior, Vol. 83 No. 3, pp. 437-449.

Makkonen, H. and Olkkonen, R. (2017), "Interactive value formation in interorganizational relationships", Marketing Theory, Vol. 17 No. 4, pp. 517-535.

Malshe, A. and Friend, S.B. (2017), "Initiating value co-creation: dealing with non-receptive customers", Journal of the Academy of Marketing Science, Vol. 46 No. 5, pp. 895920.

McColl-Kennedy, J.R., Vargo, S.L., Dagger, T.S., Sweeney, J.C. and Kasteren, Y.V. (2012), "Health care customer value cocreation practice styles", Journal of Service Research, Vol. 15 No. 4, pp. 370-389.

MacInnis, D.J., 2011. A framework for conceptual contributions in marketing. Journal of Marketing, 75(4), pp.136-154.

Moorman, C. (2018), “Call for papers. Journal of Marketing special issue: better marketing for a better world", available at: https:/www.ama.org/2018/11/20/call-for-papersjournal-of-marketing-special-issue-better-marketing-for-a-better-world/. 
Moring, J., Fuhrman, R. and Zauszniewski, J.A. (2011), “Interrelatedness of proactive coping, reactive coping, and learned resourcefulness", Measurement and Evaluation in Counseling and Development, Vol. 44 No. 4, pp. 204-214.

Olaronke, I., Oluwaseun, O. and Rhoda, I. (2017), "State of the art: a study of human-robot interaction in healthcare", International Journal of Information Engineering and Electronic Business, Vol. 9 No. 3, pp. 43-55.

Paredes, M.R., Barrutia, J.M. and Echebarria, C. (2014), "Resources for value co-creation in e-commerce: a review", Electronic Commerce Research, Vol. 14 No. 2, pp. 111136.

Perreault, W.D.J. and Leigh, L.E. (1989), "Reliability of nominal data based on qualitative judgments”, Journal of Marketing Research, Vol. 26 No. 2, pp. 135-148.

Peters, L.D., Löbler, H., Brodie, R.J., Breidbach, C.F., Hollebeek, L.D., Smith, S.D., Sörhammar, D. and Varey, R.J. (2014), “Theorizing about resource integration through service-dominant logic", Marketing Theory, Vol. 14 No. 3, pp. 249-268.

Plé, L. (2016), “Studying customers' resource integration by service employees in interactional value co-creation", Journal of Services Marketing, Vol. 30 No. 2, pp. 152-164.

Plé, L. (2017), "Why do we need research on value co-destruction?", Journal of Creating Value, Vol. 3 No. 2, pp. 162-169.

Plé, L. and Chumpitaz Cáceres, R. (2010), "Not always co-creation: introducing interactional co-destruction of value in service-dominant logic", Journal of Services Marketing, Vol. 24 No. 6, pp. 430-437.

Quach, S. and Thaichon, P. (2017), "From connoisseur luxury to mass luxury: value cocreation and co-destruction in the online environment", Journal of Business Research, Vol. 81, pp. 163-172. 
Robertson, N., Polonsky, M. and McQuilken, L. (2014), “Are my symptoms serious Dr Google? A resource-based typology of value co-destruction in online selfdiagnosis", Australasian Marketing Journal, Vol. 22 No. 3, pp. 246-256.

Ryff, C.D. and Keyes, C.L.M. (1995), “The structure of psychological well-being revisited”, Journal of Personality and Social Psychology, Vol. 69 No. 4, pp. 719-727.

Scheer, L.K., Miao, C.F. and Palmatier, R.W. (2015), "Dependence and interdependence in marketing relationships: meta-analytic insights", Journal of the Academy of Marketing Science, Vol. 43 No. 6, pp. 694-712.

Schwarzer, R. and Taubert, S. (2002), “Tenacious goal pursuits and striving toward personal growth: proactive coping”, in Frydenberg, E. (Ed.), Beyond Coping: Meeting Goals, Visions and Challenges, Oxford University Press, London, pp. 19-35.

Shephardson, D. (2019), "FAA to meet with U.S. airlines, pilot unions on Boeing 737 MAX”, available at: https://www.reuters.com/article/us-ethiopia-airplane-faa/faa-tomeet-with-u-s-airlines-pilot-unions-on-boeing-737-max-idUSKCN1RN2NE (accessed 13 April 2019)

Sirgy, M.J. and Lee, D.J. (1996), "Setting socially responsible marketing objectives", European Journal of Marketing, Vol. 30 No. 5, pp. 20-34.

Sirgy, M.J., Uysal, M. and Kruger, S. (2017), "Towards a benefits theory of leisure wellbeing”, Applied Research in Quality of Life, Vol. 12 No. 1, pp. 205-228.

Smith, A.M. (2013), "The value co-destruction process: a customer resource perspective", European Journal of Marketing, Vol. 47 No. 11/12, pp. 1889-1909.

Sparrow, R. (2016), “Robots in aged care: a dystopian future?”, AI \& Society, Vol. 31 No. 4, pp. $445-454$.

Spohrer, J., Maglio, P.P., Bailey, J. and Gruhl, D., (2007), “Steps toward a science of service systems", Computer, Vol. 40 No. 1, pp.71-77. 
Stieler, M., Weismann, F. and Germelmann, C.C. (2014), “Co-destruction of value by spectators: the case of silent protests", European Sport Management Quarterly, Vol. 14 No. 1, pp. 72-86.

Suh, E., Diener, E. and Fujita, F. (1996), "Events and subjective well-being: only recent events matter", Journal of Personality and Social Psychology, Vol. 70 No. 5, pp. 1091-1102.

Sweeney, J.C., Danaher, T.S. and McColl-Kennedy, J.R., (2015), “Customer effort in value cocreation activities: improving quality of life and behavioral intentions of health care customers", Journal of Service Research, Vol. 18 No. 3, pp.318-335.

Taylor, M. (2011), Public Policy in the Community, Palgrave Macmillan, Hampshire, UK.

Tranfield, D., Denyer, D. and Smart, P. (2003), “Towards a methodology for developing evidence-informed management knowledge by means of systematic review", British Journal of Management, Vol. 14 No. 3, pp. 207-222.

Uppström, E. and Lönn, C.M. (2017), “Explaining value co-creation and co-destruction in egovernment using boundary object theory", Government Information Quarterly, Vol. 34 No. 3, pp. 406-420.

Vafeas, M., Hughes, T. and Hilton, T. (2016), “Antecedents to value diminution”, Marketing Theory, Vol. 16 No. 4, pp. 469-491.

Vargo, S.L. and Lusch, R.F. (2004), "Evolving to a new dominant logic for marketing", Journal of Marketing, Vol. 68 No. 1, pp. 1-17.

Vargo, S.L. and Lusch, R.F. (2008), "Service-dominant logic: continuing the evolution", Journal of the Academy of Marketing Science, Vol. 36 No. 1, pp. 1-10.

Vargo, S.L. and Lusch, R.F. (2016), "Institutions and axioms: an extension and update of service-dominant logic”, Journal of the Academy of Marketing Science, Vol. 44 No. 1, pp. 5-23. 
Vargo, S.L., Maglio, P.P. and Akaka, M.A. (2008), “On value and value co-creation: a service systems and service logic perspective”, European Management Journal, Vol. 26 No. 3, pp. 145-152.

Wetzel, H.A., Hammerschmidt, M. and Zablah, A.R. (2014), "Gratitude versus entitlement: A dual process model of the profitability implications of customer prioritization", Journal of Marketing, Vol. 78 No. 3, pp. 1-19.

Williams, B.N., Kang, S.C., and Johnson, J. (2016), “(Co)-contamination as the dark side of co-production: public value failures in co-production processes", Public Management Review, Vol. 18 No. 5, pp. 692-717.

$\mathrm{Xu}$, Y., Tronvoll, B. and Edvardsson, B., (2014), "Recovering service failure through resource integration”, The Service Industries Journal, Vol. 34 No. 16, pp.1253-1271.

Zeitz, G. (1980), “Interorganizational dialectics”, Administrative Science Quarterly, Vol. 25 No. 1 , pp. $72-88$.

Zhang, T., Lu, C., Torres, E. and Chen, P.J. (2018), "Engaging customers in value co-creation or co-destruction online", Journal of Services Marketing, Vol. 32 No. 1, pp. 57-69. 
Table 1 Typology of resource misintegration manifestations

\begin{tabular}{|c|c|c|c|}
\hline Type & & $\begin{array}{l}\text { Intentionality and } \\
\text { stage of resource } \\
\text { integration }\end{array}$ & Examples \\
\hline $\begin{array}{l}\text { 1. Lack of resources } \\
\text { to integrate }\end{array}$ & $\begin{array}{l}\text { Unavailability } \\
\text { of resources or } \\
\text { belief of such } \\
\text { by at least one } \\
\text { interacting } \\
\text { actor }\end{array}$ & $\begin{array}{l}\text { Accidental or } \\
\text { deliberate } \\
\text { misintegration in } \\
\text { terms of accessing } \\
\text { resources }\end{array}$ & $\begin{array}{l}\text { - An elderly man living alone fails to receive essential services because he has no } \\
\text { confidence in using the Internet to engage in social services. } \\
\text { - A physically handicapped person is unable to use the convenient underground } \\
\text { railway service because of a lack of lifts. } \\
\text { - A migrant waitress struggles to convey customer orders accurately because of } \\
\text { poor language ability. } \\
\text { - Inadequate numbers of aged-care staff mean nursing home residents are left } \\
\text { unattended for extended periods. } \\
\text { - Call-center staff are frustrated by a new CRM system as they have not been } \\
\text { trained to capitalize on up-to-date customer information for their interactions. } \\
\text { - A local grocery store does not offer enough choice of stock for customers to } \\
\text { want to shop there. } \\
\text { The Louvre Museum is forced to turn away tourists because of excessive } \\
\text { demand on a summer weekend. }\end{array}$ \\
\hline $\begin{array}{l}\text { 2. Blocked access to } \\
\text { integrate resources }\end{array}$ & $\begin{array}{l}\text { Deliberate } \\
\text { restriction or } \\
\text { prevention of } \\
\text { resource } \\
\text { integration } \\
\text { by at least one } \\
\text { interacting } \\
\text { actor }\end{array}$ & $\begin{array}{l}\text { Deliberate } \\
\text { misintegration in } \\
\text { terms of accessing } \\
\text { resources }\end{array}$ & $\begin{array}{l}\text { - Citizens are denied access to community housing because of their ethnicity. } \\
\text { - An exclusive private club only accepts affluent, well-connected people referred } \\
\text { by existing members. } \\
\text { - A large retailer does not provide a regional wine producer with shelf space to } \\
\text { - A manice local customers. } \\
\text { strategy as requested information from the organization is not forthcoming. }\end{array}$ \\
\hline $\begin{array}{l}\text { 3. Unwillingness to } \\
\text { integrate resources }\end{array}$ & $\begin{array}{l}\text { Deliberate } \\
\text { withholding or } \\
\text { withdrawal of }\end{array}$ & Deliberate & $\begin{array}{l}\text { - A student regularly skips school as an expression of defiance. } \\
\text { - A patient refuses a life-saving blood transfusion because of religious beliefs. } \\
\text { - A couple refuses to give permission for the donation of their son's organs }\end{array}$ \\
\hline
\end{tabular}




\begin{tabular}{|c|c|c|c|}
\hline & $\begin{array}{l}\text { resources by at } \\
\text { least one } \\
\text { interacting } \\
\text { actor }\end{array}$ & $\begin{array}{l}\text { misintegration in } \\
\text { terms of accessing } \\
\text { resources }\end{array}$ & $\begin{array}{l}\text { because of mistrust of health professionals. } \\
\text { A major dental surgery de-markets a segment of consumers deemed to be } \\
\text { unprofitable, leaving them with fewer local options. }\end{array}$ \\
\hline $\begin{array}{l}\text { 4. Misunderstanding } \\
\text { of how to integrate } \\
\text { resources }\end{array}$ & $\begin{array}{l}\text { Failure to } \\
\text { understand } \\
\text { how to } \\
\text { correctly } \\
\text { integrate } \\
\text { resources by at } \\
\text { least one } \\
\text { interacting } \\
\text { actor }\end{array}$ & $\begin{array}{l}\text { Accidental } \\
\text { misintegration in } \\
\text { terms of adapting } \\
\text { resources }\end{array}$ & $\begin{array}{l}\text { A service provider and agent jointly misinterpret customer requirements, } \\
\text { resulting in customer dissatisfaction. } \\
\text { - Inadequate coordination between allied health services results in a piecemeal } \\
\text { approach to treat a patient. } \\
\text { - A client believes she supplied her divorce lawyer with information necessary for } \\
\text { a satisfactory settlement but did not declare important pre-marital financial } \\
\text { investments as she deems this information irrelevant. } \\
\text { - Following complaints from some spectators, the "Mexican Wave" is banned by } \\
\text { a sporting association, denying many fans entertainment and fun. }\end{array}$ \\
\hline $\begin{array}{l}\text { 5. Disagreement on } \\
\text { how to integrate } \\
\text { resources }\end{array}$ & $\begin{array}{l}\text { Failure to } \\
\text { agree on how } \\
\text { best to } \\
\text { integrate } \\
\text { resources by at } \\
\text { least two } \\
\text { interacting } \\
\text { actors }\end{array}$ & $\begin{array}{l}\text { Accidental or } \\
\text { deliberate } \\
\text { misintegration in } \\
\text { terms of adapting } \\
\text { resources }\end{array}$ & $\begin{array}{l}\text { - A homeowner argues with a real estate agent about how much to invest in } \\
\text { renovating a house in preparation for sale. } \\
\text { - A customer-oriented cashier who enjoys interacting with regular customers is } \\
\text { allocated frequent shifts to supervise the self-service registers despite her } \\
\text { disapproval. } \\
\text { - A patient feels his doctor has recommended excessive screening tests because he } \\
\text { is overly concerned with 'risk management'. } \\
\text { - A reseller disagrees with a manufacturer on the nature of point-of-purchase } \\
\text { promotions and the retail price to be set. }\end{array}$ \\
\hline $\begin{array}{l}\text { 6. } \\
\text { integration of } \\
\text { resources }\end{array}$ & $\begin{array}{l}\text { The deliberate } \\
\text { concealment or } \\
\text { misrepresentati } \\
\text { on of resource } \\
\text { integration by } \\
\text { at least one }\end{array}$ & $\begin{array}{l}\text { Deliberate } \\
\text { misintegration in } \\
\text { terms of adapting } \\
\text { resources }\end{array}$ & $\begin{array}{l}\text { - A customer staying at a 5-star hotel fakes an anniversary for a free bottle of } \\
\text { wine, registers a false complaint to obtain compensation and uses the room to } \\
\text { conduct illegal business. } \\
\text { - A young, single mother blogs about her fictitious terminal cancer to attract large } \\
\text { donations from the public to fund her bogus treatment. } \\
\text { - A business-to-business salesperson misleads a client about the effectiveness of } \\
\text { an expensive software application to meet sales targets. }\end{array}$ \\
\hline
\end{tabular}




\begin{tabular}{|c|c|c|c|}
\hline & $\begin{array}{l}\text { interacting } \\
\text { actor }\end{array}$ & & $\begin{array}{l}\text { - A used car salesperson does not share a car's accident history with a potential } \\
\text { buyer to make the sale. } \\
\text { - An online betting service uses customer data to offer vulnerable consumers } \\
\text { incentives to gamble. } \\
\text { - A chief of staff to a major bank receives lucrative commissions from approving } \\
\text { over-inflated invoices from suppliers. }\end{array}$ \\
\hline 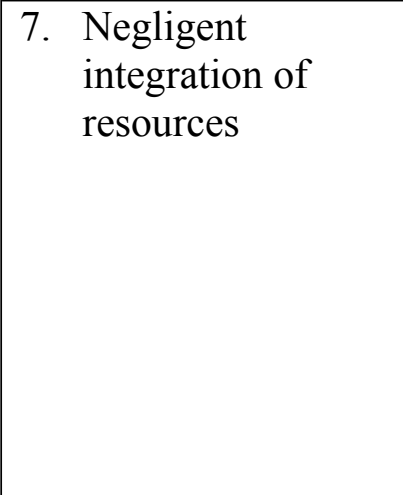 & $\begin{array}{l}\text { Deliberate } \\
\text { inattention and } \\
\text { /or } \\
\text { carelessness in } \\
\text { the integration } \\
\text { of resources by } \\
\text { at least one } \\
\text { interacting } \\
\text { actor }\end{array}$ & $\begin{array}{l}\text { Deliberate } \\
\text { misintegration in } \\
\text { terms of adapting } \\
\text { resources }\end{array}$ & $\begin{array}{l}\text { A customer does not make the effort to give his tax accountant receipts for } \\
\text { charity donations, so he does not receive tax concessions for these. } \\
\text { - A client provides a consultancy with a sloppy brief that excludes information } \\
\text { essential for a project. } \\
\text { - A hospitality worker cannot be bothered sharing his management expertise with } \\
\text { the struggling café he works, for even though his advice would make a } \\
\text { significant difference. } \\
\text { - A financial institution randomly charges customers for financial advice they do } \\
\text { not receive as the key account managers are distracted by meeting revenue } \\
\text { targets. }\end{array}$ \\
\hline $\begin{array}{ll}\text { 8. } & \text { Incapacity to } \\
& \text { integrate resources }\end{array}$ & $\begin{array}{l}\text { Disqualificatio } \\
\mathrm{n} \text { to integrate } \\
\text { resources by at } \\
\text { least one } \\
\text { interacting } \\
\text { actor }\end{array}$ & $\begin{array}{l}\text { Deliberate } \\
\text { misintegration in } \\
\text { terms of combining } \\
\text { and applying } \\
\text { resources }\end{array}$ & $\begin{array}{l}\text { - A drunk client demands that his lawyer change his will after an argument with } \\
\text { his children. } \\
\text { - A mother alters her sick child's diet from information she has read on the } \\
\text { Internet, contrary to advice given by a maternal health nurse. } \\
\text { - A real estate agent continues to practice even though he has recent criminal } \\
\text { record. } \\
\text { - A passenger is denied travel by an airline because her emotional-support animal } \\
\text { is a peacock. }\end{array}$ \\
\hline \begin{tabular}{|ll} 
9. & Excessive \\
& integration of \\
& resources
\end{tabular} & $\begin{array}{l}\text { Extreme } \\
\text { application of } \\
\text { resources by at } \\
\text { least one }\end{array}$ & $\begin{array}{l}\text { Accidental or } \\
\text { deliberate } \\
\text { misintegration in } \\
\text { terms of combining } \\
\text { and applying }\end{array}$ & $\begin{array}{l}\text { - An obsessed fan hangs around the football club to attract the attention of a } \\
\text { particular player at every training session and game. He makes an enormous } \\
\text { effort to speak with the player face-to-face and comments on the player's } \\
\text { performance every day using the club's Twitter, Instagram and Facebook } \\
\text { accounts. }\end{array}$ \\
\hline
\end{tabular}




\begin{tabular}{|l|l|l|l|}
\hline & $\begin{array}{l}\text { interacting } \\
\text { actor }\end{array}$ & resources & $\begin{array}{l}\text { - } \begin{array}{l}\text { A customer having a drink in a bar over-shares his troubles with the bartender, } \\
\text { expecting social support. } \\
\text { A hotel employee offers overly attentive service and unqualified corporate } \\
\text { privileges to a client she strongly favors. }\end{array} \\
\text { A teenage Australian schoolboy hacks into Apple's secure computer systems on } \\
\text { multiple occasions over a year because he is a huge fan of the company. }\end{array}$ \\
\hline $\begin{array}{l}\text { 10. Coercive } \\
\text { integration of } \\
\text { resources }\end{array}$ & $\begin{array}{l}\text { Involuntary, } \\
\text { forced or } \\
\text { constrained } \\
\text { resource } \\
\text { integration of } \\
\text { at least one } \\
\text { interacting } \\
\text { actor }\end{array}$ & $\begin{array}{l}\text { Deliberate } \\
\text { misintegration in } \\
\text { terms of combining } \\
\text { and applying } \\
\text { resources }\end{array}$ & $\begin{array}{l}\text { A disadvantaged customer with few financial resources is intimidated into } \\
\text { working with a "loan shark" to survive. }\end{array}$ \\
$\begin{array}{l}\text { A maternal nurse persuades parents to purchase expensive baby formula and } \\
\text { vitamins for their children as she receives incentives from the manufacturers for } \\
\text { her referrals. } \\
\text { A high-value customer makes unreasonable demands on the service provider on } \\
\text { service-level expectations and price. } \\
\text { A young woman is forced into performing commercial sex acts by traffickers } \\
\text { operating under the guise of a legitimate modeling agent. }\end{array}$ \\
\hline
\end{tabular}


Table 2 Potential causes of resource misintegration manifestations

\begin{tabular}{|c|c|}
\hline Resource misintegration manifestations & Potential causes: \\
\hline 1. Lack of resources to integrate & $\begin{array}{l}\text { - Lack of capability } \\
\text { - Low self-efficacy }\end{array}$ \\
\hline 2. Blocked access to integrate resources & $\begin{array}{l}\text { - } \text { Biases } \\
\text { - Stereotyping } \\
\text { - Prejudices } \\
\text { - Norms } \\
\text { - Power }\end{array}$ \\
\hline 3. Unwillingness to integrate resources & $\begin{array}{l}\text { - Voluntary deprivation } \\
\text { - Defiance } \\
\text { - Sabotage } \\
\text { - Control } \\
\text { - Revenge } \\
\text { - No perceived value of interaction }\end{array}$ \\
\hline $\begin{array}{l}\text { 4. Misunderstanding of how to integrate } \\
\text { resources }\end{array}$ & $\begin{array}{l}\text { - Lack of information, training and/or } \\
\text { socialization } \\
\text { - Lack of customization } \\
\text { - Lack of empathy }\end{array}$ \\
\hline $\begin{array}{l}\text { 5. Disagreement on how to integrate } \\
\text { resources }\end{array}$ & $\begin{array}{l}\text { - Conflict } \\
\text { - Power } \\
\text { - Control } \\
\text { - Self-serving } \\
\text { - Lack of empathy } \\
\text { - Dogmatism }\end{array}$ \\
\hline 6. Deceptive integration of resources & $\begin{array}{l}\text { - } \text { Opportunism } \\
\text { - } \text { Misbehavior } \\
\text { - } \text { Sensation-seeking } \\
\text { - } \text { Dark triad personality traits } \\
\text { (Machiavellianism, psychopathy and } \\
\text { narcissism) }\end{array}$ \\
\hline 7. Negligent integration of resources & $\begin{array}{l}\text { - Ambivalence } \\
\text { - Apathy } \\
\text { - } \text { Low involvement } \\
\text { - } \text { Laziness }\end{array}$ \\
\hline 8. Incapacity to integrate resources & $\begin{array}{l}\text { - Disqualification } \\
\text { - Ineligibility } \\
\text { - Inexperience }\end{array}$ \\
\hline
\end{tabular}




\begin{tabular}{|c|c|}
\hline 9. Excessive integration of resources & $\begin{array}{l}\text { - Obsession } \\
\text { - Fanaticism } \\
\text { - Addiction } \\
\text { - Anxiety }\end{array}$ \\
\hline 10. Coercive integration of resources & $\begin{array}{l}\text { - } \text { Perceived dependence } \\
\text { - Lack of alternatives } \\
\text { - } \text { Lack of control and agency } \\
\text { - } \text { Threats and pressure } \\
\text { - } \text { Power } \\
\text { - } \quad \text { Dominance }\end{array}$ \\
\hline
\end{tabular}




\section{Figure 1 VCD conceptual framework: linking resource misintegration manifestations with reduced well-being}




Web Appendix I An Overview of Value Co-destruction Process Literature

\begin{tabular}{|c|c|c|c|c|c|c|c|}
\hline Source & VCD process or alternative perspective & \begin{tabular}{|l|} 
Core citation(s) \\
used to develop \\
theoretical \\
framework \\
\end{tabular} & Conceptual basis & "Causes" of VCD & $\begin{array}{l}\text { VCD outcomes (if } \\
\text { applicable) }\end{array}$ & $\begin{array}{l}\text { Mitigators (if } \\
\text { applicable) }\end{array}$ & Paper type \\
\hline $\begin{array}{l}\text { Plé and } \\
\text { Chumpitaz } \\
\text { Cáceres (2010) }\end{array}$ & $\begin{array}{l}\text { Coined the term 'co-destruction' as an } \\
\text { antonym of 'co-creation'; "VCD is an } \\
\text { interactional process between service systems } \\
\text { that results in a decline in at least one of the } \\
\text { systems' well-being" Pg. } 431\end{array}$ & $\begin{array}{l}\text { - Lush and Vargo } \\
\text { (2006b) } \\
\text { - Lush et al. (2007) }\end{array}$ & $\begin{array}{l}\text { Service-dominant } \\
\text { logic }\end{array}$ & $\begin{array}{l}\text { - Accidental and/or intentional } \\
\text { misuse of one's own and others' } \\
\text { service system resources }\end{array}$ & & & Conceptual \\
\hline $\begin{array}{l}\text { Echeverri and } \\
\text { Skålén (2011) }\end{array}$ & $\begin{array}{l}\text { Service providers and customers drawing on } \\
\text { incongruent elements of practices cause } \\
\text { value co-destruction, representing the } \\
\text { downside of interactive value formation. }\end{array}$ & $\begin{array}{l}\text { - Schau et al. } \\
\text { (2009) } \\
\text { - Plé and } \\
\text { Chumpitaz } \\
\text { Cáceres (2010) }\end{array}$ & $\begin{array}{l}\text { Service-dominant } \\
\text { logic and practice } \\
\text { theory }\end{array}$ & $\begin{array}{l}\text { - Incongruent elements of practices, } \\
\text { such as informing, greeting, } \\
\text { delivering, charging and helping }\end{array}$ & & & $\begin{array}{l}\text { Empirical } \\
\text { (Qualitative) }\end{array}$ \\
\hline $\begin{array}{l}\text { Lefebvre and Plé } \\
\text { (2011) }\end{array}$ & $\begin{array}{l}\text { A relational breakdown between focal actors } \\
\text { and their networks in the business-to- } \\
\text { business context. }\end{array}$ & $\begin{array}{l}\text { - } \text { Plé and } \\
\text { Chumpitaz } \\
\text { Cáceres (2010) }\end{array}$ & $\begin{array}{l}\text { Service-dominant } \\
\text { logic }\end{array}$ & $\begin{array}{l}\text { - Accidental and/or intentional } \\
\text { misuse of resources and/or } \\
\text { misalignment of processes }\end{array}$ & & & Conceptual \\
\hline $\begin{array}{l}\text { Cova and } \\
\text { Paranque (2012) }\end{array}$ & $\begin{array}{l}\text { A desire to maximize gains from a brand and } \\
\text { increase financial performance can reverse a } \\
\text { value creation process and result in a brand } \\
\text { value destruction process. }\end{array}$ & $\begin{array}{l}\text { - Cova and White } \\
\text { (2010) }\end{array}$ & $\begin{array}{l}\text { Service-dominant } \\
\text { logic and brand } \\
\text { communities }\end{array}$ & $\begin{array}{l}\text { - Attempt to increase brand } \\
\text { valuation through pressure to } \\
\text { monetarization or exploitation of } \\
\text { consumers is unacceptable and } \\
\text { creates resentment. }\end{array}$ & $\begin{array}{l}\text { - Decreased brand } \\
\text { valuation }\end{array}$ & & $\begin{array}{l}\text { Empirical } \\
\text { (Qualitative) }\end{array}$ \\
\hline Smith (2013) & $\begin{array}{l}\text { Failure of resource integration process to co- } \\
\text { create expected value; loss spirals negatively } \\
\text { affect well-being and customer attempts to } \\
\text { engage in coping strategies. }\end{array}$ & $\begin{array}{l}\text { - Plé and } \\
\text { Chumpitaz } \\
\text { Cáceres (2010) }\end{array}$ & $\begin{array}{l}\text { Service-dominant } \\
\text { logic and } \\
\text { conservation of } \\
\text { resources }\end{array}$ & $\begin{array}{l}\text { - Organizational failure to fulfill } \\
\text { resource offer } \\
\text { - } \begin{array}{l}\text { Customer experiences loss of } \\
\text { stored resources } \\
\text { - Failure in resource integration } \\
\text { process }\end{array} \\
\end{array}$ & $\begin{array}{l}\text { - } \text { Reduced } \\
\text { customer and } \\
\text { organizational } \\
\text { well-being }\end{array}$ & & $\begin{array}{l}\text { Empirical } \\
\text { (Qualitative) }\end{array}$ \\
\hline $\begin{array}{l}\text { Kashif and Ting } \\
\text { (2014) }\end{array}$ & When actors fail to play their expected roles. & \begin{tabular}{|l|} 
- Plé and \\
Chumpitaz \\
Cáceres (2010) \\
\end{tabular} & $\begin{array}{l}\text { Service quality and } \\
\text { service-dominant } \\
\text { logic } \\
\end{array}$ & - Actor fails to play role & & & $\begin{array}{l}\text { Empirical } \\
\text { (Qualitative) }\end{array}$ \\
\hline $\begin{array}{l}\text { Paredes et al. } \\
\text { (2014) }\end{array}$ & $\begin{array}{l}\text { Combination of firm or customer resources } \\
\text { integrated in a negative form leads to value } \\
\text { co-destruction. }\end{array}$ & $\begin{array}{l}\text { - Plé and } \\
\text { Chumpitaz } \\
\text { Cáceres (2010) }\end{array}$ & $\begin{array}{l}\text { Service-dominant } \\
\text { logic }\end{array}$ & $\begin{array}{l}\text { - Combination of different } \\
\text { resources (firm and customer; } \\
\text { positive and negative) can have a } \\
\text { negative effect on value } \\
\text { perceptions. }\end{array}$ & & & $\begin{array}{l}\text { Literature } \\
\text { synthesis }\end{array}$ \\
\hline $\begin{array}{l}\text { Robertson et al. } \\
\text { (2014) }\end{array}$ & $\begin{array}{l}\text { When resources are misused in both service } \\
\text { processes and service outcomes. }\end{array}$ & $\begin{array}{l}\text { - Plé and } \\
\text { Chumpitaz } \\
\text { Cáceres (2010) }\end{array}$ & $\begin{array}{l}\text { Service-dominant } \\
\text { logic and resource } \\
\text { theory }\end{array}$ & $\begin{array}{l}\text { - Misuse of resources due to lack of } \\
\text { cooperation, inability to assess } \\
\text { credibility of online health } \\
\text { information, lack of health } \\
\text { literacy, skewed quality of health } \\
\text { content in online systems, lack of } \\
\text { physical presence and visual } \\
\text { feedback, complexity of } \\
\text { technology and limited service } \\
\text { provider support } \\
\text { - Misuse of knowledge resources }\end{array}$ & \begin{tabular}{|l} 
- Detrimental \\
health outcomes \\
- Consumer \\
distress \\
- Consumer in \\
agony from \\
health problems \\
- Escalation of \\
health anxiety
\end{tabular} & $\begin{array}{l}\text { Service provider } \\
\text { offering: } \\
\text { - Quality online } \\
\text { - } \text {-alth content } \\
\text { Improved e- } \\
\text { health literacy } \\
\text { - Increased } \\
\text { service } \\
\text { provider } \\
\text { support }\end{array}$ & Conceptual \\
\hline
\end{tabular}




\begin{tabular}{|c|c|c|c|c|c|c|c|c|c|c|c|}
\hline \multicolumn{2}{|c|}{\begin{tabular}{|l}
$\begin{array}{l}\text { Stieler } \text { et al. } \\
(2014)\end{array}$ \\
\end{tabular}} & \multicolumn{2}{|c|}{$\begin{array}{l}\text { The interplay between actors that results in } \\
\text { diminished value when compared with at } \\
\text { least one service actor's expected } \\
\text { enhancement of well-being. }\end{array}$} & \multicolumn{2}{|c|}{$\begin{array}{l}\text { - Plé and } \\
\text { Chumpitaz } \\
\text { Cáceres (2010) } \\
\text { - Echeverri and } \\
\text { Skålén (2011) } \\
\end{array}$} & \multicolumn{2}{|c|}{$\begin{array}{l}\text { Service-dominant } \\
\text { logic and sport } \\
\text { value framework }\end{array}$} & $\begin{array}{l}- \text { Atmosphere within the stadium } \\
\text { such as fan behavior in the form of } \\
\text { negative emotions or negative } \\
\text { behaviours. }\end{array}$ & & & $\begin{array}{l}\text { Empirical } \\
\text { (Qualitative) }\end{array}$ \\
\hline \multicolumn{2}{|c|}{ Xu et al. (2014) } & \multicolumn{2}{|c|}{$\begin{array}{l}\text { Co-created service recovery fails in the } \\
\text { absence of resources or mismatches in their } \\
\text { integration. }\end{array}$} & \multicolumn{2}{|c|}{$\begin{array}{l}- \text { Dong et al. } \\
(2008)\end{array}$} & \multicolumn{2}{|c|}{$\begin{array}{l}\text { Co-creation and } \\
\text { justice theory }\end{array}$} & $\begin{array}{l}\text { - Lack of resources in integration } \\
\text { process or mismatch in integration } \\
\text { practice }\end{array}$ & $\begin{array}{l}\text { - Co-created } \\
\text { service recovery } \\
\text { failure }\end{array}$ & & $\begin{array}{l}\text { Empirical } \\
\text { (Quantitative) }\end{array}$ \\
\hline \multicolumn{2}{|c|}{$\begin{array}{l}\text { Becker et al. } \\
(2015)\end{array}$} & \multicolumn{2}{|c|}{$\begin{array}{l}\text { Value is co-created and co-destructed } \\
\text { through various expressions of approach- } \\
\text { avoidance motivation. }\end{array}$} & \multicolumn{2}{|c|}{$\begin{array}{l}\text { - Echeverri and } \\
\text { Skålén (2011) }\end{array}$} & \multicolumn{2}{|c|}{$\begin{array}{l}\text { Service-dominant } \\
\text { logic and } \\
\text { avoidance- } \\
\text { approach } \\
\text { motivation }\end{array}$} & $\begin{array}{l}\text { - Avoidance motivation as a basis } \\
\text { for co-destruction Interpretation of } \\
\text { negative stimuli increases } \\
\text { avoidance motivation }\end{array}$ & \begin{tabular}{|l} 
failure \\
\end{tabular} & & $\begin{array}{l}\text { Empirical } \\
\text { (Qualitative) }\end{array}$ \\
\hline \multicolumn{2}{|c|}{$\begin{array}{l}\text { Caridà et al. } \\
\text { (2015) }\end{array}$} & \multicolumn{2}{|c|}{$\begin{array}{l}\text { Value is co-created through actor's resource- } \\
\text { integrating efforts in virtual brand } \\
\text { communities. }\end{array}$} & \multicolumn{2}{|c|}{$\begin{array}{l}\text { - Skålén, Pace and } \\
\text { Cova (2015) }\end{array}$} & \multicolumn{2}{|c|}{$\begin{array}{l}\text { Service-dominant } \\
\text { logic and practice } \\
\text { theory }\end{array}$} & $\begin{array}{l}\text { - Integration of available resources } \\
\text { - Operation on available resource } \\
\text { - Actor's assessment of value in } \\
\text { context }\end{array}$ & $\begin{array}{l}\text { - Emerging value } \\
\text { can be positive } \\
\text { or negative } \\
\text { depending on } \\
\text { resource } \\
\text { (mis)alignment }\end{array}$ & & $\begin{array}{l}\text { Empirical } \\
\text { (Qualitative) }\end{array}$ \\
\hline \multicolumn{2}{|c|}{$\begin{array}{l}\text { Carù and Cova } \\
\text { (2015) }\end{array}$} & \multicolumn{2}{|c|}{$\begin{array}{l}\text { Collective practices between service } \\
\text { providers and co-consuming groups can lead } \\
\text { to co-creation and co-destruction; these } \\
\text { practices are ambivalent in nature and } \\
\text { capable of co-creation/co-destruction. }\end{array}$} & \multicolumn{2}{|c|}{$\begin{array}{l}\text { - Plé and } \\
\text { Chumpitaz } \\
\text { Cáceres (2010) } \\
\text { - Echeverri and } \\
\text { Skålén (2011) }\end{array}$} & \multicolumn{2}{|c|}{$\begin{array}{l}\text { Service-dominant } \\
\text { logic and consumer } \\
\text { culture theory }\end{array}$} & $\begin{array}{l}\text { - Unmanageability of ambivalent } \\
\text { practices of performing, judging, } \\
\text { volunteering and queuing }\end{array}$ & & & $\begin{array}{l}\text { Empirical } \\
\text { (Qualitative) }\end{array}$ \\
\hline \multicolumn{2}{|c|}{ Geer (2015) } & \multicolumn{2}{|c|}{$\begin{array}{l}\text { 'Defective co-creation' occurs when } \\
\text { consumers fail to provide mental, physical } \\
\text { and/or emotional inputs of sufficient quality } \\
\text { and quantity to facilitate value co-creation. }\end{array}$} & \multicolumn{2}{|c|}{$\begin{array}{l}\text { - Dysfunctional } \\
\text { consumer } \\
\text { behavior }\end{array}$} & \multicolumn{2}{|c|}{$\begin{array}{l}\text { Service-dominant } \\
\text { logic and customer } \\
\text { participation }\end{array}$} & $\begin{array}{l}\text { - Dysfunction as goods-related } \\
\text { misbehavior (e.g., fraud) } \\
\text { - Dysfunction as interpersonal } \\
\text { misbehavior (e.g., threats) } \\
\text { - Dysfunction as relational } \\
\text { misbehavior (e.g., refusal to } \\
\text { engage) }\end{array}$ & $\begin{array}{l}\text { - Obstruction of } \\
\text { co-creation value }\end{array}$ & & $\begin{array}{l}\text { Empirical } \\
\text { (Qualitative) }\end{array}$ \\
\hline $\begin{array}{l}\text { French and } \\
\text { Gordon (2015) }\end{array}$ & $\begin{array}{l}\text { Whe } \\
\text { misu } \\
\text { diser } \\
\text { inter }\end{array}$ & $\begin{array}{l}\text { esources, services or experiences are } \\
\text { 1, misappropriated (and citizens } \\
\text { ge) or used in the opposite way }\end{array}$ & $\begin{array}{ll} & \text { Plé } \\
\text { Cá } \\
\text { Ec } \\
\text { Sk }\end{array}$ & $\begin{array}{l}\text { and } \\
\text { eres, (2010) } \\
\text { everri and } \\
\text { lén }(2011)\end{array}$ & Value & reation & $\begin{array}{l}- \text { Poo } \\
\text { and } \\
\text { unw } \\
\text { envi } \\
\text { inap } \\
\text { pers }\end{array}$ & $\begin{array}{l}\text { quality standards, training } \\
\text { interpersonal skills from staff, } \\
\text { elcoming physical } \\
\text { ronment, lack of or } \\
\text { propriate resources, or } \\
\text { onal issues in people's lives }\end{array}$ & & $\begin{array}{l}\text { Literatu } \\
\text { review }\end{array}$ & \\
\hline $\begin{array}{l}\text { Kashif a } \\
\text { Zarkada }\end{array}$ & 2015) & $\begin{array}{l}\text { When actors fail to play their expect } \\
\text { in script provided by service system. }\end{array}$ & roles & $\begin{array}{l}\text { - Plé and } \\
\text { Chumpita } \\
\text { Cáceres ( }\end{array}$ & & $\begin{array}{l}\text { Service } \\
\text { logic }\end{array}$ & & - Customer misbehavior & $\begin{array}{l}\text { - Damages } \\
\text { preconception of } \\
\text { service quality to } \\
\text { other customers } \\
\text { - Affects the } \\
\text { organization's } \\
\text { brand image } \\
\text { - Increases } \\
\text { direct/indirect } \\
\text { financial costs } \\
\text { - Reduces morale } \\
\text { of frontline } \\
\text { employees }\end{array}$ & $\begin{array}{l}\text { - Service } \\
\text { provider offers } \\
\text { information } \\
\text { regarding } \\
\text { policies }\end{array}$ & $\begin{array}{l}\text { Empirical } \\
\text { (Qualitative) }\end{array}$ \\
\hline
\end{tabular}




\begin{tabular}{|c|c|c|c|c|c|c|c|}
\hline $\begin{array}{l}\text { Laamanen and } \\
\text { Skålén (2015) }\end{array}$ & $\begin{array}{l}\text { Collective-conflictual value, in which } \\
\text { conflictual value is a result of opportunistic } \\
\text { behavior or abuse by one or several } \\
\text { interacting parties, resulting in incongruent } \\
\text { interaction practices. }\end{array}$ & \begin{tabular}{|l} 
- Echeverri and \\
Skålén (2011)
\end{tabular} & $\begin{array}{l}\text { Service-dominant } \\
\text { logic and strategic } \\
\text { action field theory }\end{array}$ & $\begin{array}{l}\text { - Challenges collective identity } \\
\text { formed around grievances against } \\
\text { incumbents } \\
\text { - Disparate goals } \\
\text { - Power inequality } \\
\text { - Lacking degree of control } \\
\text { - Withholding/withdrawing } \\
\text { resources } \\
\text { - Resource misuse }\end{array}$ & $\begin{array}{l}\text { - (Non)fulfilment } \\
\text { of provider's } \\
\text { value } \\
\text { proposition in } \\
\text { customer's } \\
\text { value-in-use } \\
\text { - Dissatisfaction } \\
\text { - Disloyalty }\end{array}$ & & Conceptual \\
\hline $\begin{array}{l}\text { Marcos-Cuevas et } \\
\text { al. (2015) }\end{array}$ & $\begin{array}{l}\text { Discrepancy and divergence in risk-sharing } \\
\text { partnerships create platforms for value co- } \\
\text { destruction. }\end{array}$ & $\begin{array}{l}\text { - Plé and } \\
\text { Chumpitaz } \\
\text { Cáceres (2010) }\end{array}$ & $\begin{array}{l}\text { Service-dominant } \\
\text { logic }\end{array}$ & $\begin{array}{l}\text { - Divergent expectations of risk } \\
\text { sharing }\end{array}$ & & & $\begin{array}{l}\text { Empirical } \\
\text { (Qualitative) }\end{array}$ \\
\hline $\begin{array}{l}\text { Osei-Frimpong et } \\
\text { al. (2015) }\end{array}$ & $\begin{array}{l}\text { Knowledge conflict between actors in a } \\
\text { service encounter, which can lead to value } \\
\text { destruction. }\end{array}$ & $\begin{array}{l}\text { - Plé and } \\
\text { Chumpitaz } \\
\text { Cáceres (2010) }\end{array}$ & $\begin{array}{l}\text { Service-dominant } \\
\text { logic }\end{array}$ & $\begin{array}{l}\text { - Knowledge conflict } \\
\text { - One party's unexpected behavior }\end{array}$ & & & $\begin{array}{l}\text { Empirical } \\
\text { (Qualitative) }\end{array}$ \\
\hline Dey et al. (2016) & $\begin{array}{l}\text { Value can be co-destructed due to contextual } \\
\text { limitations, resource constraints (both } \\
\text { operant and operand) at the customer end, or } \\
\text { producers. }\end{array}$ & $\begin{array}{l}\text { - Plé and } \\
\text { Chumpitaz } \\
\text { Cáceres (2010) } \\
\text { - Smith (2013) } \\
\end{array}$ & $\begin{array}{l}\text { Service-dominant } \\
\text { logic }\end{array}$ & $\begin{array}{l}\text { - Lack of technology appropriation } \\
\text { by users } \\
\text { - Lack of understanding of } \\
\text { marketing dynamics by marketers }\end{array}$ & & & $\begin{array}{l}\text { Empirical } \\
\text { (Qualitative) }\end{array}$ \\
\hline Hill et al. (2016) & $\begin{array}{l}\text { An anti-service belief which guides service } \\
\text { provider actions toward prisoners, leading to } \\
\text { a reduction of well-being. }\end{array}$ & $\begin{array}{l}\text { Plé and } \\
\text { Chumpitaz } \\
\text { Cáceres (2010) }\end{array}$ & $\begin{array}{l}\text { Participatory action } \\
\text { research }\end{array}$ & $\begin{array}{l}\text { - Reducing humanity in service } \\
\text { interactions } \\
\text { - Exploitation of inmates due to } \\
\text { opportunistic behavior from } \\
\text { prisons } \\
\text { - Power imbalance and restriction } \\
\text { of service } \\
\text { - Anti-service oppositional culture } \\
\text { - Deliberate anti-service }\end{array}$ & $\begin{array}{l}\text { - Emotional and } \\
\text { behavioral } \\
\text { consequences }\end{array}$ & $\begin{array}{l}\text { Prisoner } \\
\text { coping by } \\
\text { taking service } \\
\text { quality into } \\
\text { own hands } \\
\text { - Coping } \\
\text { through the } \\
\text { development } \\
\text { of an alternate } \\
\text { economy }\end{array}$ & $\begin{array}{l}\text { Empirical } \\
\text { (Qualitative) }\end{array}$ \\
\hline Plé (2016) & $\begin{array}{l}\text { When resources whose use should result in } \\
\text { value co-creation are used by one actor (here, } \\
\text { the employee) in a manner that is not } \\
\text { congruent with the way the other actor (here, } \\
\text { the customer) expects. }\end{array}$ & $\begin{array}{l}\text { - Echeverri and } \\
\text { Skålén (2011) } \\
\text { - Plé and } \\
\text { Chumpitaz } \\
\text { Cáceres (2010) }\end{array}$ & $\begin{array}{l}\text { Service-dominant } \\
\text { logic, focusing on } \\
\text { resource integration }\end{array}$ & $\begin{array}{l}\text { - Accidental and intentional } \\
\text { misintegration } \\
\text { - Non-integration }\end{array}$ & $\begin{array}{l}\text { - Co-creation and } \\
\text { co-destruction of } \\
\text { value }\end{array}$ & & Conceptual \\
\hline Popp et al. (2016) & $\begin{array}{l}\text { Joint aversion to a brand by a community } \\
\text { (also called anti-brand communities), thus } \\
\text { undermining the brand's identity value. }\end{array}$ & $\begin{array}{ll}\text { - } & \text { Stieler et al. } \\
& (2014)\end{array}$ & $\begin{array}{l}\text { Service-dominant } \\
\text { logic }\end{array}$ & $\begin{array}{l}\text { - Rivalry } \\
\text { - Oppositional brand loyalty } \\
\text { - Fulfilment of self-defining needs } \\
\text { to oppose a specific brand } \\
\text { - Schadenfreude, a German term } \\
\text { denoting pleasure at another's } \\
\text { misfortune }\end{array}$ & & & $\begin{array}{l}\text { Empirical } \\
\text { (Qualitative) }\end{array}$ \\
\hline $\begin{array}{l}\text { Skourtis et al. } \\
\text { (2016) }\end{array}$ & $\begin{array}{l}\text { When a service failure occurs, some forms of } \\
\text { consumption value (functional, } \\
\text { social, emotional, epistemic and conditional) } \\
\text { are co- destroyed. }\end{array}$ & $\begin{array}{ll} & \text { Plé and } \\
& \text { Chumpitaz } \\
& \text { Cáceres (2010) }\end{array}$ & $\begin{array}{l}\text { Service-dominant } \\
\text { logic and D.A.R. T } \\
\text { model }\end{array}$ & - Service failure & & $\begin{array}{l}\text { - Mechanism of } \\
\text { value } \\
\text { restoration }\end{array}$ & Conceptual \\
\hline $\begin{array}{l}\text { Vafes et al. } \\
\text { (2016) }\end{array}$ & $\begin{array}{l}\text { Coins term 'value diminution', as opposed to } \\
\text { value co-destruction, for instances in which } \\
\text { realized value is sub-optimal and less than } \\
\text { potential value. }\end{array}$ & $\begin{array}{l}\text { - Plé and } \\
\text { Chumpitaz } \\
\text { Cáceres (2010) }\end{array}$ & $\begin{array}{l}\text { Service-dominant } \\
\text { logic }\end{array}$ & $\begin{array}{l}\text { Client-related causes: } \\
\text { - Absence of trust } \\
\text { - Inadequate communication } \\
\text { - Inadequate co-ordination }\end{array}$ & $\begin{array}{l}\text { - Sub-optimal } \\
\text { creative output } \\
\text { and potential } \\
\text { marketplace } \\
\text { performance }\end{array}$ & & $\begin{array}{l}\text { Empirical } \\
\text { (Qualitative) }\end{array}$ \\
\hline
\end{tabular}




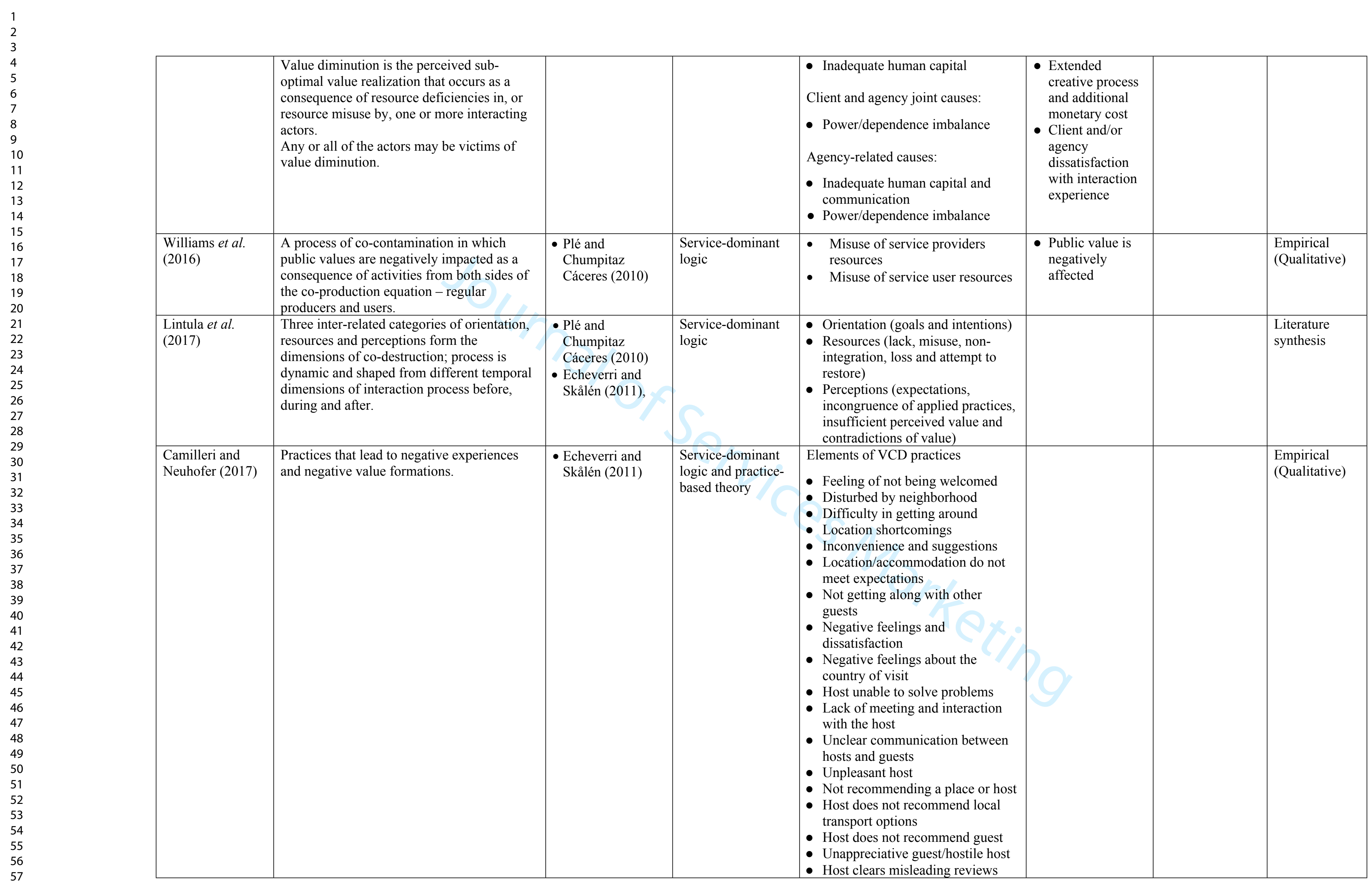




\begin{tabular}{|c|c|c|c|c|c|c|c|}
\hline $\begin{array}{l}\text { Chavi et al. } \\
\text { (2017) }\end{array}$ & $\begin{array}{l}\text { Value co-creation and value co-destruction } \\
\text { are contingent in B2B service networks due } \\
\text { to the chain of interactions upstream to } \\
\text { downstream. }\end{array}$ & $\begin{array}{l}\text { - Plé and } \\
\text { Chumpitaz } \\
\text { Cáceres (2010) }\end{array}$ & $\begin{array}{l}\text { Service-dominant } \\
\text { logic }\end{array}$ & $\begin{array}{l}\text { - Nature of interacting actors, their } \\
\text { activities and mobilization of } \\
\text { resources in a network }\end{array}$ & & & $\begin{array}{l}\text { Empirical } \\
\text { (Qualitative) }\end{array}$ \\
\hline $\begin{array}{l}\text { Daunt and Harris } \\
\text { (2017) }\end{array}$ & $\begin{array}{l}\text { Showrooming behavior comprises differing } \\
\text { degrees of accumulative value co-destruction } \\
\text { and co-creation behavior across online and } \\
\text { offline channels. }\end{array}$ & $\begin{array}{l}\text { - Plé and } \\
\text { Chumpitaz } \\
\text { Cáceres (2010) }\end{array}$ & $\begin{array}{l}\text { Service-dominant } \\
\text { logic }\end{array}$ & $\begin{array}{l}\text { - Consumer savviness and trust in } \\
\text { online stores is associated with } \\
\text { online value co-destruction }\end{array}$ & & $\begin{array}{l}\text { - Shopping } \\
\text { enjoyment }\end{array}$ & $\begin{array}{l}\text { Empirical } \\
\text { (Quantitative) }\end{array}$ \\
\hline $\begin{array}{l}\text { Farquhar and } \\
\text { Robson (2017) }\end{array}$ & $\begin{array}{l}\text { Customers destroy value by } \\
\text { misusing/misunderstanding how to integrate } \\
\text { operant resources, affecting system value } \\
\text { destruction. }\end{array}$ & $\begin{array}{l}\text { - Plé and } \\
\text { Chumpitaz } \\
\text { Cáceres (2010) }\end{array}$ & $\begin{array}{l}\text { Service-dominant } \\
\text { logic }\end{array}$ & - Operant resource misuse & $\begin{array}{l}\text { - Customers } \\
\text { destroy value } \\
\text { beyond the } \\
\text { immediate firm } \\
\text { impact through } \\
\text { the service } \\
\text { system at the } \\
\text { micro, meso and } \\
\text { macro levels }\end{array}$ & & Conceptual \\
\hline $\begin{array}{l}\text { Leo and } \\
\text { Zainuddin (2017) }\end{array}$ & $\begin{array}{l}\text { Systemic processes reduce value for social } \\
\text { marketing services, supporting behavioral } \\
\text { change. }\end{array}$ & $\begin{array}{l}\text { - Plé and } \\
\text { Chumpitaz } \\
\text { Cáceres (2010) }\end{array}$ & Value creation & $\begin{array}{l}\text { - Incongruent resource application } \\
\text { and misuse of firm resources } \\
\text { impeding behavioral change } \\
\text { efforts }\end{array}$ & $\begin{array}{l}\text { - } \text { Reduced use of } \\
\text { service } \\
\text { - Strategic } \\
\text { behavioral } \\
\text { actions of } \\
\text { service users } \\
\text { - Service } \\
\text { termination }\end{array}$ & & $\begin{array}{l}\text { Empirical } \\
\text { (Qualitative) }\end{array}$ \\
\hline $\begin{array}{l}\text { Lintula et al. } \\
\text { (2017) }\end{array}$ & $\begin{array}{l}\text { Critical service interactions in augmented } \\
\text { reality mobile games can ensue to value co- } \\
\text { destruction. }\end{array}$ & $\begin{array}{l}\text { - Plé and } \\
\text { Chumpitaz } \\
\text { Cáceres (2010) }\end{array}$ & $\begin{array}{l}\text { Service-dominant } \\
\text { logic }\end{array}$ & $\begin{array}{l}\text { - Contradictions } \\
\text { - Expectations } \\
\text { - Incongruent applied practices } \\
\text { - Insufficient perceived value } \\
\text { - Resource loss, misuse or non- } \\
\text { integration }\end{array}$ & $\begin{array}{l}\text { Negative value } \\
\text { outcomes, such } \\
\text { as frustration, } \\
\text { humiliation and } \\
\text { obsession, occur } \\
\text { from co- } \\
\text { destructed value }\end{array}$ & & $\begin{array}{l}\text { Empirical } \\
\text { (Qualitative,) }\end{array}$ \\
\hline $\begin{array}{l}\text { Makkonen and } \\
\text { Olkkonen (2017) }\end{array}$ & $\begin{array}{l}\text { Interactive value formation process as an } \\
\text { interplay between resource integration } \\
\text { and a service system; the interplay features } \\
\text { dynamic interchange of value co-creative, } \\
\text { non-creative and co-destructive interaction } \\
\text { episodes, whose accumulation dictates the } \\
\text { relationship outcome of co-creation, non- } \\
\text { creation and co-destruction. }\end{array}$ & $\begin{array}{l}\text { - Plé and } \\
\text { Chumpitaz } \\
\text { Cáceres (2010) } \\
\text { - Echeverri and } \\
\text { Skålén(2011) } \\
\text { - Laamanen and } \\
\text { Skålén(2015) }\end{array}$ & $\begin{array}{l}\text { Customer-dominant } \\
\text { logic and value in } \\
\text { context }\end{array}$ & $\begin{array}{l}\text { - Interplay between resource } \\
\text { integration and multi-level service } \\
\text { system (macro-, meso- and micro- } \\
\text { level structure) }\end{array}$ & & & $\begin{array}{l}\text { Empirical } \\
\text { (Qualitative) }\end{array}$ \\
\hline $\begin{array}{l}\text { Malone et al. } \\
\text { (2017) }\end{array}$ & $\begin{array}{l}\text { Incongruent practices give rise to emotions in } \\
\text { consumption experience that shape value } \\
\text { destruction process. }\end{array}$ & $\begin{array}{l}\text { - Heinonen et al. } \\
(2010) \\
\text { Heinonen et al. } \\
(2013)\end{array}$ & $\begin{array}{l}\text { Service-dominant } \\
\text { logic }\end{array}$ & $\begin{array}{l}\text { - Emotions as an operant resource } \\
\text { shape value destruction process }\end{array}$ & & & $\begin{array}{l}\text { Empirical } \\
\text { (Qualitative) }\end{array}$ \\
\hline $\begin{array}{l}\text { Quach and } \\
\text { Thaichon (2017) }\end{array}$ & $\begin{array}{l}\text { The way customers use resources during } \\
\text { interactions with a brand contributes to } \\
\text { customer experiences that lead to value } \\
\text { destruction. }\end{array}$ & $\begin{array}{l}\text { - Plé and } \\
\text { Chumpitaz } \\
\text { Cáceres (2010) }\end{array}$ & $\begin{array}{l}\text { Customer-dominant } \\
\text { logic and social } \\
\text { resource theory }\end{array}$ & $\begin{array}{l}\text { - Resources such as love, status, } \\
\text { information and services when } \\
\text { misused }\end{array}$ & & $\begin{array}{l}\text { - Expectations } \\
\text { determine the } \\
\text { way people } \\
\text { use resources } \\
\text { when } \\
\text { interacting } \\
\text { with a brand }\end{array}$ & $\begin{array}{l}\text { Empirical } \\
\text { (Qualitative) }\end{array}$ \\
\hline
\end{tabular}




\begin{tabular}{|c|c|c|c|c|c|c|c|}
\hline $\begin{array}{l}\text { Uppström and } \\
\text { Lönn (2017) }\end{array}$ & $\begin{array}{l}\text { Value is co-created and co-destroyed when } \\
\text { IS artifacts are used for collaboration. }\end{array}$ & $\begin{array}{l}- \text { Plé and } \\
\text { Chumpitaz } \\
\text { Cáceres (2010) } \\
\text { - Vartiainen and } \\
\text { Tuunanen (2014) }\end{array}$ & $\begin{array}{l}\text { Co-creation and } \\
\text { boundary object } \\
\text { theory }\end{array}$ & $\begin{array}{l}\text { - IS artifacts as boundary objects } \\
\text { create loss of expert local } \\
\text { knowledge and personal } \\
\text { relationships in the switch to } \\
\text { digital platforms } \\
\text { - Trusting digital information, } \\
\text { despite its questionable quality }\end{array}$ & & $\begin{array}{l}- \text { Boundary } \\
\text { complexity } \\
\text { increases risk } \\
\text { of co- } \\
\text { destructive } \\
\text { outcomes }\end{array}$ & \begin{tabular}{|l|} 
Empirical \\
(Qualitative)
\end{tabular} \\
\hline $\begin{array}{l}\text { Zainuddin et al. } \\
\text { (2017) }\end{array}$ & $\begin{array}{l}\text { Value dimensions have the potential to be } \\
\text { created or destroyed in behavior } \\
\text { maintenance. }\end{array}$ & $\begin{array}{l}\text { - Plé and } \\
\text { Chumpitaz } \\
\text { Cáceres (2010) }\end{array}$ & $\begin{array}{l}\text { Value creation; } \\
\text { self-determination } \\
\text { theory }\end{array}$ & $\begin{array}{l}\text { - Barriers (physical and mental } \\
\text { discomfort, time and effort) to } \\
\text { behavioral maintenance }\end{array}$ & $\begin{array}{l}\text { - Functional and } \\
\text { emotional value } \\
\text { have the } \\
\text { potential to be } \\
\text { destroyed }\end{array}$ & $\begin{array}{l}\text { - Financial } \\
\text { incentives and } \\
\text { disincentives } \\
\text { - Augmented } \\
\text { products to } \\
\text { support } \\
\text { socially } \\
\text { desirable } \\
\text { behaviors }\end{array}$ & $\begin{array}{l}\text { Empirical } \\
\text { (Qualitative) }\end{array}$ \\
\hline Čaić et al. (2018) & $\begin{array}{l}\text { A perception of the role of social robots in } \\
\text { supporting residents to achieve desired value } \\
\text { co-creation or potential value destruction. }\end{array}$ & $\begin{array}{l}\text { - Plé and } \\
\text { Chumpitaz } \\
\text { Cáceres (2010) } \\
\text { - Echeverri and } \\
\text { Skålén (2011) } \\
\end{array}$ & $\begin{array}{l}\text { Service-dominant } \\
\text { logic }\end{array}$ & $\begin{array}{l}\text { - Social robots perceived as } \\
\text { intruders, replacements or } \\
\text { deactivators }\end{array}$ & & & Empirical \\
\hline Hardyman (2018) & $\begin{array}{l}\text { A discrete event } \\
\text { (i.e., a patient having an allergic reaction } \\
\text { while undergoing a specific } \\
\text { chemotherapy treatment), or an overall } \\
\text { process (i.e., the process of being } \\
\text { diagnosed) that occurs during cancer-related } \\
\text { service use, that is perceived by } \\
\text { the recipient as having negative } \\
\text { consequences, and which culminates in value } \\
\text { co-destruction. }\end{array}$ & \begin{tabular}{|l} 
- Plé and \\
Chumpitaz \\
Cáceres (2010) \\
- Laamanen and \\
Skålén (2015)
\end{tabular} & $\begin{array}{l}\text { Service-dominant } \\
\text { logic }\end{array}$ & $\begin{array}{l}\text { - Poor interpersonal and } \\
\text { communication skills of the staff } \\
\text { - Resource misuse } \\
\text { - Organizational factors (constraints } \\
\text { and issues) } \\
\text { - Lack of access to resources } \\
\end{array}$ & & & $\begin{array}{l}\text { Empirical } \\
\text { (Qualitative) }\end{array}$ \\
\hline Järvi et al. (2018) & $\begin{array}{l}\text { A failed interaction process that results in at } \\
\text { least one actor's decrease in well-being and } \\
\text { takes place in a specific type of relationship; } \\
\text { perceived concept of VCD entails process } \\
\text { and outcome. }\end{array}$ & $\begin{array}{l}\text { - Plé and } \\
\text { Chumpitaz } \\
\text { Cáceres (2010) } \\
\text { - Makkonen and } \\
\text { Olkkonen (2017) }\end{array}$ & $\begin{array}{l}\text { Service-dominant } \\
\text { logic }\end{array}$ & $\begin{array}{l}\text { - } \text { Customer misbehavior } \\
\text { - Absence of information } \\
\text { - Insufficient level of trust } \\
\text { - Mistakes } \\
\text { - Inability to serve or change } \\
\text { - Blaming } \\
\text { - Absence of clear expectations } \\
\end{array}$ & $\begin{array}{l}\text { - Value co- } \\
\text { destruction }\end{array}$ & & $\begin{array}{l}\text { Empirical } \\
\text { (Qualitative) }\end{array}$ \\
\hline $\begin{array}{l}\text { Zhang et al. } \\
\text { (2018) }\end{array}$ & $\begin{array}{l}\text { Actors can jointly co-destruct service or } \\
\text { experience in an online context. }\end{array}$ & $\begin{array}{ll}\text { - } & \text { Plé and } \\
& \text { Chumpitaz } \\
& \text { Cáceres (2010) }\end{array}$ & $\begin{array}{l}\text { Service-dominant } \\
\text { logic }\end{array}$ & $\begin{array}{l}\text { - Warning other customers } \\
\text { - Revenge intentions } \\
\text { - Employees rudeness, lack of } \\
\text { empathy and negative word of } \\
\text { mouth about employer } \\
\text { - Organizational structural forces } \\
\text { such as indifferent attitude, } \\
\text { confrontation, cheating, lack of a } \\
\text { complaint outlet and delayed } \\
\text { service or recovery during } \\
\text { negatively valenced engagement }\end{array}$ & 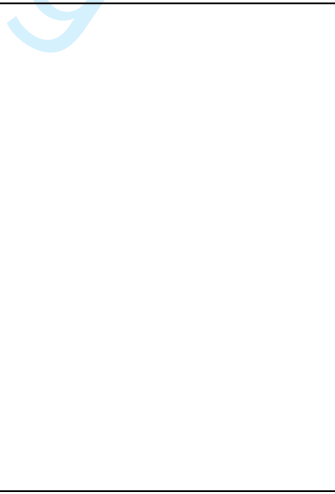 & & $\begin{array}{l}\text { Empirical } \\
\text { (Qualitative) }\end{array}$ \\
\hline $\begin{array}{l}\text { Cabiddu et al. } \\
\text { (2019) }\end{array}$ & $\begin{array}{l}\text { Social interactions and resource integration } \\
\text { practices can cause negative variation in } \\
\text { capita property. }\end{array}$ & $\begin{array}{l}\text { - Lombardo and } \\
\text { Cabiddu (2017) }\end{array}$ & Practice theory & $\begin{array}{l}\text { - Gaining access to and potential to } \\
\text { exploitation of capital through use } \\
\text { or conversion }\end{array}$ & $\begin{array}{l}\text { - VCD practices } \\
\text { destroy different } \\
\text { forms of capital: }\end{array}$ & & $\begin{array}{l}\text { Empirical } \\
\text { (Qualitative) }\end{array}$ \\
\hline
\end{tabular}




\begin{tabular}{|c|c|c|c|c|c|c|}
\hline & & & & & $\begin{array}{l}\text { economic, } \\
\text { cultural, social } \\
\text { and symbolic }\end{array}$ & \\
\hline $\begin{array}{l}\text { Dolan et al. } \\
\text { (2019) }\end{array}$ & $\begin{array}{l}\text { Tourist complaining on social media is } \\
\text { theorized as process of value formation that } \\
\text { carries the potential for both positive (value } \\
\text { co-creation) and negative (value co- } \\
\text { destruction) consequences. Thus, not all } \\
\text { negative experiences result in co-destruction } \\
\text { of value but instead also offer opportunities } \\
\text { for value co-creation. }\end{array}$ & $\begin{array}{l}\text { - Plé and } \\
\text { Chumpitaz } \\
\text { Cáceres (2010) } \\
\text { - Echeverri and } \\
\text { Skålén (2011) }\end{array}$ & $\begin{array}{l}\text { - Service-dominant } \\
\text { logic } \\
\text { - Practice theory }\end{array}$ & $\begin{array}{l}\text { Solution-seeking practice results } \\
\text { in failure to respond (non- } \\
\text { engaging) or an } \\
\text { unsuitable/incongruent response } \\
\text { from the firm } \\
\text { - Social support is not received } \\
\text { from others, or the support offered } \\
\text { is incongruent with the consumer's } \\
\text { expectations. } \\
\text { - Incongruent corporate responses } \\
\text { lead to the co-destruction of value, } \\
\text { as the complaining consumers do } \\
\text { not successfully achieve their } \\
\text { goals of warning other consumers }\end{array}$ & & $\begin{array}{l}\text { Empirical } \\
\text { (Qualitative) }\end{array}$ \\
\hline Kim et al. (2019) & $\begin{array}{l}\text { Customer to customer value co-destruction is } \\
\text { conceptualized as a direct and indirect } \\
\text { interactional process among customers that } \\
\text { results in the deterioration of at least one } \\
\text { party's perceived value. }\end{array}$ & $\begin{array}{l}\text { Plé and Chumpitaz } \\
\text { Cáceres (2010) }\end{array}$ & $\begin{array}{l}\text { Service-dominant } \\
\text { logic; expectancy } \\
\text { violation theory }\end{array}$ & - Customer dysfunctional behavior & $\begin{array}{l}\text { Deterioration } \\
\text { of Economic, } \\
\text { social, } \\
\text { emotional and } \\
\text { epistemic value }\end{array}$ & $\begin{array}{l}\text { Empirical } \\
\text { (Quantitative) }\end{array}$ \\
\hline
\end{tabular}

1 "Causes" is a generic label used to describe the reasons, triggers and antecedents identified by VCD studies. 2 All references not cited are available in the main text.

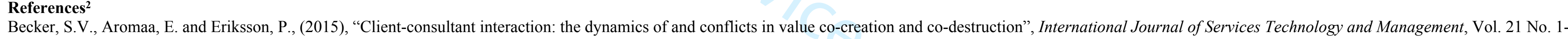
3, pp.40-54.

Daunt, K.L. and Harris, L.C., (2017), “Consumer showrooming: value co-destruction. Journal of Retailing and Consumer Services”, Vol. 38, pp.166-176.

Dolan, R., Seo, Y. and Kemper, J. (2019), "Complaining practices on social media in tourism: a value co-creation and co-destruction perspective”, Tourism Management, Vol. 73 , pp. 35-45.

Farquhar, J.D. and Robson, J. (2017), "Selective demarketing: when customers destroy value", Marketing Theory, Vol. 17 No. 2, pp. 165-182.

French, J. and Gordon, R. (2015), Strategic Social Marketing, Sage, Los Angeles, USA.

Hardyman, W. (2017), "Trajectories of value: an exploration of value co-creation and destruction in cancer services", doctoral dissertation, Cardiff University.

Järvi, H., Kähkönen, A.K. and Torvinen, H. (2018), “When value co-creation fails: reasons that lead to value co-destruction”, Scandinavian Journal of Management, Vol. 34 No. 1, pp. 63-77.

Osei-Frimpong, K., Wilson, A. and Owusu-Frimpong, N. (2015), "Service experiences and dyadic value co-creation in healthcare service delivery: a CIT approach", Journal of Service Theory and Practice, Vol. 25 No. 4, pp. 443-

462 .

Kashif, M. and Ting, H., (2014), "Service-orientation and teaching quality: business degree students' expectations of effective teaching", Asian Education and Development Studies, Vol 3 No. 2, pp.163-180.

Kim, K., Byon, K.K. and Baek, W. (2019), "Customer-to-customer value co-creation and co-destruction in sporting events", Service Industries Journal, https://doi.org/10.1080/02642069.2019.1586887.

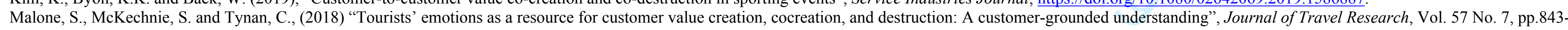

855.

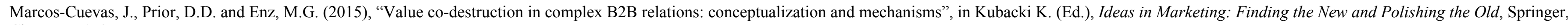
Cham, pp. 153 .

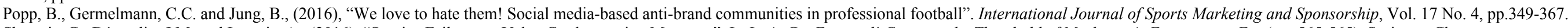
Skourtis, G., Décaudin, J.M. and Ioannis, A., (2016), "Service Failures as Value Co-destruction Moments", In Let's Get Engaged! Crossing the Threshold of Marketing's Engagement Era (pp. 565-565). Springer, Cham.

Zainuddin, N., Dent, K. and Tam, L., (2017), "Seek or destroy? Examining value creation and destruction in behaviour maintenance in social marketing", Journal of Marketing Management, Vol. 33 No. 5-6, pp.348-374. 